
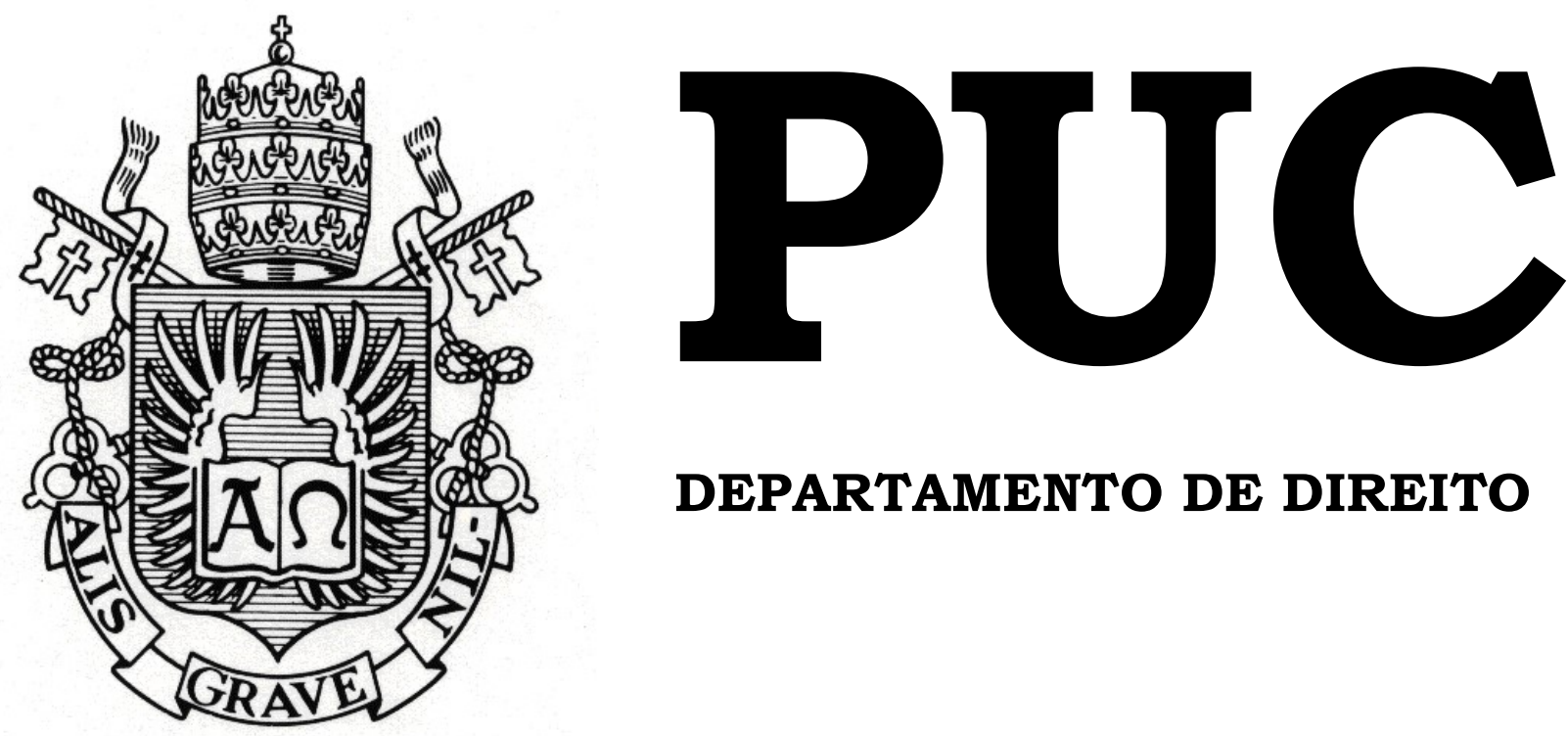

DEPARTAMENTO DE DIREITO

\title{
QUESTÕES CONTROVERTIDAS NO TRATAMENTO DOGMÁTICO DO LUCRO DA INTERVENÇÃO
}

Por

FERNANDA COACHMAN FIGUEIRA

ORIENTADOR: Marcelo Fernandez Trindade

\section{2}

PONTIFÍCIA UNIVERSIDADE CATÓLICA DO RIO DE JANEIRO

RUA MARQUÊS DE SÃO VICENTE, 225 - CEP 22451-900

RIO DE JANEIRO - BRASIL 


\title{
QUESTÕES CONTROVERTIDAS NO TRATAMENTO DOGMÁTICO DO LUCRO DA INTERVENÇÃO
}

por

\section{FERNANDA COACHMAN FIGUEIRA}

\author{
Monografia apresentada ao \\ Departamento de Direito da \\ Pontificia Universidade Católica do \\ Rio de Janeiro (PUC-Rio) para a \\ obtenção do Título de Bacharel em \\ Direito.
}

Orientador: Marcelo Fernandez Trindade 


\section{AGRADECIMENTOS}

Aos meus pais, Mário e Simone, pelo amor e apoio incondicional em cada etapa da minha formação.

Ao meu irmão mais novo, Victor, a quem tanto admiro por seu equilíbrio, maturidade, e pela dedicação que deposita em tudo o que faz.

Às minhas amigas queridas, que tive a sorte de conhecer logo no primeiro período da faculdade: Alice, Brenda, Clara, Camila, Júlia, Louizi, Naomi e Vivian, os últimos cinco anos não teriam tido graça sem vocês.

Ao meu orientador e professor, Marcelo, por ter me dado a maravilhosa oportunidade de trabalhar com ele logo no início da minha vida profissional, e a quem devo minha paixão pelo Direito Civil.

Ao André Seabra, meu eterno mentor, por ter despertado meu interesse pela advocacia contenciosa e por toda confiança que depositou em mim.

À Julia Monlevade, que foi muito mais do que uma simples colega de escritório nesse ano, pela parceria constante, você foi um ponto de luz em meio ao caos.

Às minhas amigas Bruna Aleixo, Camila Kelly, e Ana Carolina Mihich, por serem mulheres fortes e inteligentes, que me inspiram.

Por fim, a todos os colegas da Trindade Sociedade de Advogados e do Ferro, Castro Neves, Daltro e Gomide Advogados, pelas lições que foram essenciais para a minha formação profissional.

Muito obrigada! 


\section{RESUMO}

FIGUEIRA, Fernanda Coachman. Questões controvertidas no tratamento do lucro da intervenção. Rio de Janeiro: 2018: 77 p. Monografia de final de curso. Departamento de Direito da Pontifícia Universidade Católica do Rio de Janeiro - PUC-Rio.

O presente estudo aborda as situações reunidas sob o rótulo de lucro da intervenção, locução que designa as hipóteses de exploração não autorizada de bens e direitos alheios de que resulta um proveito econômico para o autor da violação. Investiga-se o enquadramento dogmático do instituto, partindo de uma análise estrutural e funcional da responsabilidade civil e do enriquecimento sem causa, a fim de estabelecer, se, em que medida, e a que título a vantagem patrimonial obtida pelo interventor deve ser restituída ao titular do direito.

Palavras-Chave: Direito Civil - Responsabilidade Civil - Enriquecimento sem Causa - Lucro da Intervenção - Lucros Cessantes - Justa Causa Subsidiariedade - Indenização Punitiva - Actio in rem verso. 


\section{SUMÁRIO}

INTRODUÇÃO ............................................................................................6

Capítulo 1 - O Enquadramento Dogmático do Lucro da Intervenção. 10

1.1. A Teoria da Tripartição Funcional das Fontes de Obrigações .......... 10

1.2. O Terceiro Método de Cálculo da Indenização .................................. 19

1.3. Distinção Conceitual entre Lucro da Intervenção e Lucros Cessantes

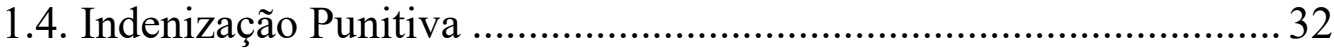

Capítulo 2 - Requisitos para a Configuração do Enriquecimento sem



2.1. Ausência de Justa Causa para o Enriquecimento ............................... 54

Capítulo 3 - A Subsidiariedade do Enriquecimento sem Causa ...........59

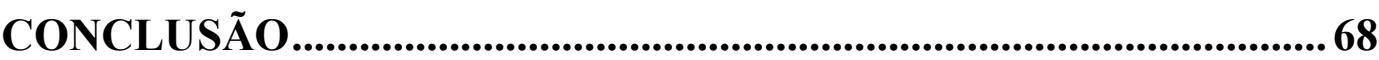

REFERÊNCIAS BIBLIOGRÁFICAS ...............................................70 


\section{LISTA DE ABREVIAÇÕES}

CRFB/88 - Constituição da República Federativa do Brasil de 1988 CC - Código Civil brasileiro de 2002 


\section{INTRODUÇÃO}

O presente trabalho se destina a empreender uma análise do fenômeno, conhecido em sede doutrinária como "lucro da intervenção", que designa a exploração desautorizada de bens, direitos, ou do trabalho alheio, de que resulta um incremento patrimonial para o transgressor.

O enquadramento dogmático do instituto assume especial relevância no panorama contemporâneo, em que se observa uma ampla gama de situações de intervenção desautorizada em bens ou direitos alheios, que proporcionam um proveito econômico para o interventor. Em certos casos, inclusive, o titular do direito não sofre qualquer dano em razão da ingerência alheia, ou, então, sofre prejuízo inferior ao lucro que foi auferido pelo ofensor com a violação aos seus direitos.

Nesta toada, a questão central da problemática consiste em elucidar (i) se, (ii) em que medida e (iii) a que título a vantagem patrimonial obtida pelo interventor deve ser restituída ao titular do direito.

A responsabilidade civil, instrumento dinâmico de proteção do patrimônio contra mutações destina-se, precipuamente, ao ressarcimento da vítima, operando-se a sua restituição ao estado anterior ao ato ilícito. Nesse contexto, o patrimônio do ofensor atua como mero coadjuvante, a quem incumbirá proporcionar a reparação integral do dano sofrido, com a pura finalidade de satisfação.

Em sintonia com essa finalidade, o artigo 944 do Código Civil, limita o objeto da obrigação de indenizar à extensão do dano sofrido. Sob esse prisma, é indiferente se o ofensor percebeu ou não um acréscimo no seu patrimônio.

A constatação de que os reflexos patrimoniais positivos da conduta lesiva sobre o patrimônio do próprio causador do dano não são levados em conta na quantificação da indenização, poderia, a princípio, ensejar a 
conclusão de que o ordenamento jurídico brasileiro não possui sanção eficaz para desestimular a adoção desse tipo de conduta.

Do ponto de vista prático, portanto, ter-se-ia que admitir que o ordenamento condescende com atos ilícitos que se afiguram financeiramente vantajosos para o ofensor. Afinal, se o dano causado à vítima, e consequentemente, a reparação devida a esse título, for inferior ao proveito econômico percebido com a usurpação do bem jurídico, seria mais cômodo ingerir-se na esfera jurídica alheia e aguardar a reação do titular, contando com as incertezas inerentes ao processo judicial, do que obter o consentimento do titular pela via contratual, e realizar, a priori, o pagamento da contraprestação que seria exigida (valor de mercado) pela fruição do direito.

Numa ordem jurídica firmada no primado da autonomia da vontade, o contrato é a principal via para a aquisição de situações subjetivas e o principal instrumento de distribuição consensual de riquezas. Se é indiferente ao interventor - sob o ponto de vista da obtenção do lucro, ainda que relevante do ponto de vista da estabilidade da exploração do bem ou direito alheio obter a permissão do titular por meio de um contrato, ou usufruir diretamente do direito, sem se preocupar em obter a autorização do titular, objetivamente, a vontade do titular passaria, para aquela finalidade, a ser irrelevante.

A atuação isolada da responsabilidade civil nesta seara acabaria por redundar no que se denominou "expropriação privada de bens e direitos alheios a preço de mercado", pois o ofensor teria que pagar, sob a rubrica de lucros cessantes, apenas o valor de mercado do bem sobre o qual se apropriou indevidamente, conservando em seu patrimônio um proveito que, em muitos casos, jamais conseguiria obter através de uma via lícita.

\footnotetext{
${ }^{1}$ A expressão é de Júlio Manuel Vieira Gomes. GOMES, Júlio Manuel Vieira. O conceito de enriquecimento, o enriquecimento forçado e os vários paradigmas do enriquecimento sem causa. Porto: Universidade Católica Portuguesa, 1998. p. 755.
} 
Não surpreende, nesse particular, que as indenizações punitivas sejam aplicadas a esmo pela jurisprudência, fruto do "sentimento de insatisfação com os institutos tradicionais" ${ }^{2}$. Na esteira desse processo, encontram cada vez mais ressonância na jurisprudência pátria as vozes que defendem que o "paradigma reparatório" da responsabilidade civil deve ser superado em favor do reconhecimento de uma função sancionatória.

Em meio ao já caótico e empírico mecanismo de quantificação adotado pelo Judiciário, a função punitiva surgiu nos tribunais brasileiros como válvula de escape ao sistema, por meio da qual se tornou possível, sem maiores reflexões acerca de critérios, parâmetros e fundamentos, fixar o quantum indenizatório reputado "justo", sobretudo quando o montante da indenização, pautado pela extensão do dano, se mostra desproporcionalmente baixo se comparado à reprovabilidade da conduta do ofensor ${ }^{3}$.

Afigura-se necessário, nesse contexto, um remédio que exerça uma função dissuasiva adequada a coibir intervenções lucrativas. Este trabalho identifica o enriquecimento sem causa como instituto vocacionado a propiciar uma sanção eficaz para as situações reunidas sob o rótulo genérico de "lucro da intervenção". Tratando-se de um instrumento de conservação estática dos patrimônios, a cláusula geral de vedação ao enriquecimento sem causa, positivada no art. 844, CC, visa à manutenção, dentro da esfera jurídica do titular, de todas as riquezas produzidas a partir dos bens que já o integram, salvo por ato de transmissão consentido ou legalmente imponível.

A fim de desempenhar essa função, o enriquecimento sem causa se volta para o transgressor, expurgando do seu patrimônio todo o incremento gerado a partir de bens e direitos alheios, e reconduzindo o lucro produzido pela intervenção ao patrimônio do titular do direito.

\footnotetext{
${ }^{2}$ MOSCATI, Enrico. Pena privata e autonomia privata. In: VV.AA. Le pene private. Milano: Giuffrè, 1985. pp. 235-249.

3 TERRA, Aline de Miranda Valverde. Função Punitiva do Dano Moral: Análise Crítica e Proposições Funcionalmente Equivalentes. In: Direito civil contemporâneo. Organização CONPEDI/UFS; REZENDE, Elcio Nacur et al. (Coords.). Florianópolis: CONPEDI, 2015a. p. 413.
} 
Sem dúvida, a questão mais tortuosa no tratamento do lucro da intervenção reside na quantificação do objeto da restituição, isto é, na determinação da extensão da obrigação de restituir. A complexidade deriva do fato de que as intervenções lucrativas são, muitas vezes, fruto da incorporação de uma situação jurídica subjetiva alheia em um processo produtivo capitaneado pelo transgressor.

Torna-se necessário, portanto, discriminar o lucro proveniente da atividade própria do interventor, do lucro sobressalente acrescido à operação econômica em virtude da utilização do bem ou direito alheio.

Esse trabalho pretende expor os critérios e soluções para a quantificação do lucro da intervenção propugnados pela doutrina, e as respectivas críticas, sem, contudo, ter qualquer ambição de exaurir o tema.

O primeiro capítulo se dedicará a situar dogmaticamente o lucro da intervenção, uma vez que o instituto se encontra na zona limítrofe entre a responsabilidade civil e o enriquecimento sem causa.

No segundo capítulo, examinar-se-ão os requisitos para a aplicação do enriquecimento sem causa, à luz do direito positivo, sustentando-se que alguns dos requisitos vislumbrados por parte da doutrina não encontram supedâneo na legislação, e acabam por atrofiar excessivamente o campo de incidência do instituto.

O terceiro capítulo se dedicará exclusivamente à interpretação do requisito da subsidiariedade, consagrado no artigo 886 do Código Civil. Ainda nesse tópico, analisar-se-á a viabilidade de atuação concomitante da actio in rem verso com a ação de indenização por responsabilidade civil para que, ao fim, se conclua pela possibilidade de as pretensões reparatória e restitutória coexistirem em uma mesma situação fática, uma vez que remetem a institutos funcionalmente distintos e não excludentes. 


\title{
CAPÍTULO 1 - O ENQUADRAMENTO DOGMÁTICO DO LUCRO DA INTERVENÇÃO
}

\subsection{A Teoria da Tripartição Funcional das Fontes de Obrigações}

A sistematização das categorias de obrigações tratadas pelo direito brasileiro permite elencar três principais regimes - negocial, reparatório e restitutório - passíveis de recondução, respectivamente, à hipótese fática que originou a relação obrigacional: negócio jurídico, dano injusto e enriquecimento sem causa.

Avulta, nesse sentido, uma tripartição funcional das obrigações, sendo possível apartar as funções executória (de um negócio legitimamente celebrado), reparatória (de um dano injustamente causado) e restitutória (de um enriquecimento injustamente auferido), a que correspondem diferentes formas de satisfação do interesse do credor.

\begin{abstract}
O interesse do credor que é tutelado em cada obrigação é suscetível de variações infinitas. Todavia, ele poderá ser sempre classificado em uma das seguintes três categorias: (a) interesse na realização das expectativas nascidas de compromissos assumidos por outra pessoa (devedor) em negócio jurídico; (b) interesse na reparação dos danos antijuridicamente causados por outra pessoa (devedor), ou, como também se poderá dizer, dos danos resultantes da violação de deveres gerais de não lesar a pessoa nem o patrimônio alheio; (c) interesse na reversão para o patrimônio de uma pessoa (credor) dos acréscimos verificados no patrimônio de outrem (devedor), quando juridicamente eles estivessem destinados àquele ${ }^{4}$.
\end{abstract}

Em suma, a identificação da função desempenhada por cada específica obrigação permite a delimitação da disciplina jurídica que regerá aquela relação obrigacional concreta. Afigura-se necessário, nessa toada, definir a qual dos regimes fundamentais de obrigação o lucro da intervenção está funcionalmente vinculado.

Pode-se afastar, de início, a inserção deste fenômeno no âmbito do regime negocial, tendo em vista que o pressuposto fático do lucro da

\footnotetext{
${ }^{4}$ NORONHA, Fernando. Direito das Obrigações: fundamentos do direito das obrigações: introdução à responsabilidade civil. v. 1. $2^{\mathrm{a}}$ ed. São Paulo: Saraiva, 2007. p. 416.
} 
intervenção consiste, precisamente, na ausência de título jurídico permissivo da exploração. No entanto, tal dissociação não decorre, por si só, da ausência de negócio jurídico prévio entre o interventor e o titular do direito.

Com efeito, o campo de atuação do lucro da intervenção não se circunscreve à seara das relações extracontratuais. O locupletamento ilícito também pode se configurar no âmbito de relações contratuais, embora, nesses casos, não decorra do simples inadimplemento, mas do fato de o inadimplemento ser o meio pelo qual se viola o direito alheio. É o que ocorre, por exemplo quando o contratante utiliza comercialmente a imagem de modelo fotográfico além dos limites autorizados em contrato, auferindo vultosos benefícios econômicos. Em situações como essa, com efeito, é a intervenção em direito da personalidade alheio, via inadimplemento contratual, que gera o enriquecimento do inadimplente ${ }^{5}$.

O inadimplemento eficiente do contrato ("efficient breach") também pode gerar um lucro para o contratante inadimplente. Tal fenômeno, em formulação sintética, se caracteriza pela realocação economicamente mais vantajosa de recursos que se haveria de destinar ao cumprimento do contrato, ensejando um benefício econômico para o contratante inadimplente ${ }^{6}$.

Mesmo nessa hipótese, a redestinação do proveito financeiro auferido pela parte inadimplente não possui supedâneo em um acordo de vontades, o que afasta a possibilidade de admissão do fenômeno do lucro da intervenção dentro do regime negocial. Inclusive, há mesmo dúvidas, diante da configuração atual do direito contratual brasileiro, se esse proveito econômico deve ser, de fato, removido do patrimônio do contratante

\footnotetext{
${ }^{5}$ TERRA, Aline de Miranda Valverde; GUEDES, Gisela Sampaio da Cruz. Considerações acerca da exclusão do lucro ilícito do patrimônio do agente ofensor. Revista da Faculdade de Direito RFD-UERJ. Rio de Janeiro, n. 28, p. 19, dez. 2015 b.

${ }^{6}$ Fernando Araújo sintetiza a problemática do inadimplemento eficiente: (...) o 'incumprimento eficiente' é o incumprimento 'lucrativo' para o devedor, é aquele que: - ou o liberta de um cumprimento que se tornou desproporcionadamente oneroso, suscitando da parte do devedor um 'efeito de substituição', que é o de procurar destinos alternativos aos recursos que empregaria no cumprimento; - ou o envolve numa relação contratual com um terceiro que lhe traz benefícios superiores àqueles que lhe adviriam do cumprimento das suas anteriores obrigações contratuais, uma relação que, em suma, novamente torna relativamente oneroso o cumprimento inicialmente assumido. ARAÚJO, Fernando. Teoria econômica do contrato. Coimbra: Almedina, 2007. p. 745.
} 
inadimplente. Afinal, desde que este cumpra a lei e as disposições dos contratos violados, relativas às penalidades decorrentes do inadimplemento, não há que se cogitar sequer de lucro ilícito, já que presente o título jurídico legítimo, justificador do incremento patrimonial - o segundo contrato ${ }^{7}$.

Ultrapassada essa digressão sobre a aplicabilidade da teoria do lucro da intervenção no bojo de relações contratuais, resta analisar o seu enquadramento dogmático na responsabilidade civil e no enriquecimento sem causa, questão que é objeto de aguda controvérsia doutrinária.

Em primeiro lugar, os institutos ostentam uma nítida diferença de foco, reflexo, aliás, dos distintos fundamentos sobre os quais se assentam. Enquanto a cláusula genérica de vedação ao enriquecimento sem causa, instituída no art. 884 do Código Civil visa à restituição do patrimônio do enriquecido ao status quo anterior ao fato gerador do enriquecimento, a responsabilidade civil tem como função precípua a recomposição do desfalque patrimonial sofrido pela vítima do ato ilícito.

CARLOS NELSON KONDER resume a distinta vocação dos dois institutos nos seguintes termos:

De um lado, a responsabilidade civil visa, com base no princípio neminem laedere, a reparar um dano sofrido pela vítima em razão de um ato ilícito (culposo) ou em virtude de uma atividade de risco (responsabilidade objetiva). Ela confere uma proteção dinâmica ao patrimônio e se volta para o ressarcimento pleno da vítima, atribuindo uma obrigação de indenizar. Já o enriquecimento sem causa é um instrumento de proteção estática do patrimônio; posto menos intenso, abarca casos que não seriam cobertos pela responsabilidade civil, uma vez que não há ilicitude (stricto sensu) ou dano. A reparação do dano sofrido, quando ocorre é sempre indireta, pois o que se busca é remover a vantagem auferida por um para transferila a quem ela era de direito ${ }^{8}$.

\footnotetext{
${ }^{7}$ Nesse sentido: De lege lata, portanto, não há norma no direito brasileiro que impeça o contratante de inadimplir contrato previamente celebrado para pactuar outro mais vantajoso. Observadas a lei e as cláusulas contratuais incidentes diante do inadimplemento, o descumprimento de contrato poderá resultar, ao fim e ao cabo, lucrativo para o inadimplente, afigurando-se mesmo duvidosa a qualificação desse lucro como ilegítimo, diante da atual configuração do direito contratual brasileiro. TERRA; GUEDES, 2015, p. 20.

${ }^{8}$ KONDER, Carlos Nelson. Enriquecimento sem causa e pagamento indevido. In: TEPEDINO, Gustavo (Coord.) Obrigações. Estudos na perspectiva civil-constitucional. Rio de Janeiro: Renovar, 2005. p. 379.
} 
Conforme referido no texto supratranscrito, o enriquecimento sem causa encerra ferramenta de conservação estática dos patrimônios. Diz-se que o instituto implementa uma proteção "estática", pois visa a reunir, no patrimônio do titular, todo o proveito econômico gerado a partir da exploração dos bens já afetos àquela universalidade de direito.

Segundo o princípio da proteção estática dos patrimônios, inferido dos arts. 182, 869, 876, 884 e 885, do Código Civil, o valor dos bens e direitos atribuídos a alguém e dos bens e direitos gerados a partir desses bens e direitos já atribuidos deve permanecer, em princípio, no patrimônio desse alguém ${ }^{9}$.

Em síntese, tal concepção garante ao titular da posição jurídica ativa o monopólio do aproveitamento econômico do bem ou direito. Estruturalmente, a proteção se assemelha àquela atribuída ao direito de propriedade, no sentido de que exibe um conteúdo negativo - consistente na possibilidade de excluir os outros de um domínio reservado - mas atribui, além disso, um conteúdo positivo - correspondente à destinação de uma utilidade.

Tal similitude estrutural não passou incólume pela doutrina, levando MENEZES LEITÃo a qualificar o enriquecimento sem causa por intervenção como "um prolongamento da eficácia do direito de propriedade, inserindose no âmbito da proteção jurídica dos bens" ${ }^{" 10}$.

A propósito da referida linha de entendimento, afirma-se:

Essa solução, que foi unanimemente seguida pela restante doutrina que fundamenta a aplicação do enriquecimento sem causa às hipóteses de ingerência em direitos reais, reside na circunstância de esses direitos não corresponderem simplesmente a um ius excludendi omnes alios (conforme defendeu a concepção personalista do direito real) mas também estabelecerem a afectação de todas as utilidades que advenham da coisa ao seu titular, possuindo assim um conteúdo da destinação. A atribuição dos direitos reais é constituída por normas de ordenação, que reservam o gozo e disposição de determinados bens aos respectivos titulares. Assim, sempre

\footnotetext{
${ }^{9}$ MICHELON Jr., Cláudio. Direito Restitutório: enriquecimento sem causa, pagamento indevido, gestão de negócios. São Paulo: Editora Revista dos Tribunais, 2007. p. 29.

${ }^{10}$ MENEZES LEITÃO, Luis Manuel Teles de. O enriquecimento sem causa no novo Código Civil brasileiro. Revista CEJ, Brasília, v. 8, n. 25, p. 27, abr./jun. 2004.
} 
que o interventor tenha retirado da coisa objecto do direito real determinadas vantagens, pode-se dizer que obteve um enriquecimento à custa do titular desse direito, uma vez que se apropriou de determinada utilidade que a ordem jurídica reservava exclusivamente a esse titular, segundo o direito da ordenação dos bens. Assim, não há lugar à restituição do enriquecimento, independentemente da circunstância de o titular do direito pretender ou não realizar o mesmo aproveitamento da coisa ${ }^{11}$.

Como o fim econômico da propriedade inclui uma destinação das utilidades proporcionadas pela coisa, o seu uso ou consumo por terceiro atribui, com base no conteúdo da destinação (Zuweisungsgehalt), uma pretensão de enriquecimento contra quem se beneficiou das utilidades da coisa. A pretensão de enriquecimento desenvolve-se, assim, organicamente a partir da propriedade e configura-se como uma pretensão da "continuação da eficácia" (Rechtsfortwirkungsanspruch) desse direito. Como tal, a pretensão de enriquecimento dirigir-se-ia primordialmente à restituição do resultado da intervenção, abrangendo todas as vantagens do uso e fruição de bens alheios ${ }^{12}$.

A ideia de que o Direito assegura ao titular de um direito o monopólio do aproveitamento econômico dos bens não é imune a críticas e relativizações.

Nesse sentido, ClÁUdio MiCHELON destaca as implicações de qualificar a conservação estática como um princípio:

O princípio da conservação estática dos patrimônios, como todo princípio, tem duas características: (a) não exclui a possibilidade de exceções em casos fundados em outros princípios que só podem ser identificados no caso concreto e (b) é formulado em linguagem que possui uma "textura aberta", necessitando de trabalho adicional, seja do legislador, seja do aplicador, para que possa alcançar casos concretos (v.g., o que exatamente significa "direitos gerador" é algo que deverá ser investigado pelo intérprete aplicador $)^{13}$.

O princípio da conservação estática, portanto, comporta relativizações, devendo ser sopesado, pelo intérprete, com outros valores implicados no caso concreto.

\footnotetext{
${ }^{11}$ LEITÃO, Luís Manuel Teles de Menezes. O enriquecimento sem causa no direito civil: estudo dogmático sobre a viabilidade da configuração unitária do instituto, face à contraposição entre as diferentes categorias de enriquecimento sem causa. Lisboa: Centro de Estudos Fiscais, 1996. p. 718. ${ }^{12}$ CAMPOS, Diogo Paredes Leite de. A subsidiariedade da obrigação de restituir o enriquecimento (1974). Coimbra: Almedina, 2003. p. 465-466.

${ }^{13}$ MICHELON Jr., 2007, p. 29.
} 
Nos direitos de propriedade, por exemplo, é possível que a atividade do interventor seja merecedora de tutela devido à inércia do titular em extrair utilidades econômicas daquele bem, tal como ocorre na tutela da posse em face da propriedade, com base no cumprimento da função social.

No contexto atual de funcionalização dos institutos jurídicos, a tutela da propriedade só se justifica à luz da função social que promove. Portanto, embora a inexistência de autorização legal ou negocial possa indiciar ausência de "justa causa" para o enriquecimento, a ponderação da ausência de título jurídico formal com os demais valores relevantes para a delimitação da (in)justiça do enriquecimento deve ser realizada casuisticamente.

No que tange ao fundamento axiológico da vedação ao locupletamento sem causa, o instituto se ancora na teoria do conteúdo da destinação jurídica dos bens e direitos (em contraposição à teoria do deslocamento patrimonial), segundo a qual:

(...) tudo quanto estes bens sejam capazes de render ou produzir pertence, em princípio, de acordo com o conteúdo da destinação ou afectação de tais direitos, ao respectivo titular. A pessoa que, intrometendo-se nos bens jurídicos alheios, consegue uma vantagem patrimonial, obtém-na à custa do titular do respectivo direito, mesmo que este não estivesse disposto a praticar os actos donde a vantagem procede $(\ldots)^{14}$.

Conclui-se que o enriquecimento é reputado ilícito justamente porque, de acordo com a ordenação substancial dos bens aprovada pelo Direito, ele deveria pertencer a seu titular.

De outro giro, a responsabilidade civil é funcionalmente voltada para a tutela da pessoa da vítima, corolário da positivação, na Constituição Federal, da dignidade da pessoa humana como fundamento da República (art. $1^{\circ}$, III, CRFB/88).

Nesse sentido, as eventuais vantagens auferidas pelo causador do dano são, de regra, indiferentes para fins de deflagração da obrigação de indenizar,

\footnotetext{
${ }^{14}$ ANTUNES VARELA, João de Matos. Das Obrigações em geral. v. 1. $7^{\mathrm{a}}$ ed. Coimbra: Almedina, 1991, p. 492-493.
} 
pautada exclusivamente pela existência e extensão de dano injusto, quantificação operada a partir da variação patrimonial observada na esfera jurídica da vítima.

Maria Celina Bodin de Moraes destaca a releitura dos objetivos perseguidos pelo instituto da responsabilidade civil a partir da legalidade constitucional:

A constitucionalização do direito dos danos impôs, como se viu, a releitura da própria função primordial da responsabilidade civil. $\mathrm{O}$ foco que tradicionalmente recaía sobre a pessoa do causador do dano que por seu ato reprovável deveria ser punido, deslocou-se no sentido da tutela especial garantida à vítima do dano injusto, que merece ser reparada. A punição do agente pelo dano causado, preocupação pertinente ao direito penal, perde a importância no âmbito cível para a reparação da vítima pelos danos sofridos ${ }^{15}$

O fenômeno acima descrito ficou conhecido como "giro conceitual da responsabilidade civil do ato ilícito para o dano injusto" ${ }^{16}$, este último entendido como a lesão a interesse jurídico. O sistema, que antes orbitava em torno da obrigação do ofensor de responder por suas culpas, teve seu eixo deslocado para o direito da vítima de ter reparadas as suas perdas.

Em síntese, desvincula-se a noção de antijuridicidade da conduta, daquela de injustiça do dano. No influxo dos novos tempos, o juízo de licitude do comportamento fica relegado a segundo plano, cedendo espaço a um juízo de merecimento de tutela (meritevolezza), o qual permite detectar outros danos ressarcíveis, que não aqueles resultantes da prática de um ato ilícito.

Tal concepção reflete, ainda, a erradicação, na seara da responsabilidade civil, de considerações pertinentes ao grau de reprovabilidade da conduta do ofensor, exceto diante da eventual apuração

\footnotetext{
${ }^{15}$ BODIN DE MORAES, Maria Celina. A constitucionalização do direito civil e seus efeitos sobre a responsabilidade civil. In: SOUZA NETO, Cláudio Pereira; SARMENTO, Daniel (Coord.). A constitucionalização do direito: fundamentos teóricos e aplicações específicas. Rio de Janeiro: Lumen Juris, 2007. p. 439.

16 GOMES, Orlando. Tendências modernas na teoria da responsabilidade civil. In: DI FRANCESCO, J. R. P. (Org.). Estudos em Homenagem ao Professor Silvio Rodrigues. São Paulo: Saraiva, 1980. p. 293.
} 
de culpa levíssima, hipótese na qual a indenização poderá ser equitativamente reduzida (e jamais aumentada), com fundamento no artigo 944, parágrafo único, do Código Civil.

\section{Conforme destaca FERNANDO NORONHA:}

"Consistindo fundamentalmente na obrigação de reparar o dano causado, a responsabilidade civil em princípio não tem como medida a gravidade da conduta do lesante, nem outros fatores subjetivos, mas unicamente a extensão do dano causado $[\ldots] "{ }^{17}$

Além da instituição de uma cláusula geral de responsabilidade objetiva por atividades de risco (art. 927, parágrafo único, CC) ${ }^{18}$, a objetivação do requisito da "culpa" mesmo nos casos regidos pela responsabilidade subjetiva permitiu um expressivo aumento das hipóteses de danos ressarcíveis. Abandonou-se a concepção anímica ou psicológica da culpa, fortemente contaminada por caráter moralizador, em favor de conceito normativo, que se revela na ideia de erro de conduta, obtido pela comparação entre $\mathrm{o}$ ato do infrator e o standard de comportamento esperado dele naquela situação específica.

Com efeito, a erosão da culpa enquanto filtro de reparação foi tão drástica, que alguns doutrinadores passaram a enxergar a responsabilidade civil como mera aglutinação de "processos técnicos de que se pode lançar mão para assegurar às vítimas o direito à reparação dos danos injustamente sofridos" $" 19$. Não restam dúvidas, portanto, de que a função moralizadora, outrora considerada como aspecto nuclear do instituto, cedeu espaço à função reparatória.

\footnotetext{
17 NORONHA, Fernando. Direito das Obrigações: fundamentos do direito das obrigações: introdução à responsabilidade civil. v. 1. $2^{\mathrm{a}}$ ed. São Paulo: Saraiva, 2007. p. 416.

18 "Parágrafo único. Haverá obrigação de reparar o dano, independentemente de culpa, nos casos especificados em lei, ou quando a atividade normalmente desenvolvida pelo autor do dano implicar, por sua natureza, risco para os direitos de outrem.".

19 FACCHINI NETO, Eugênio. Da responsabilidade civil no novo Código. In. SARLET, Ingo Wolfgang (Org.). O novo Código Civil e a Constituição. Porto Alegre: Livraria do Advogado, 2006. p. 180-181.
} 
Nesse diapasão, o art. 944 do Código Civil estabeleceu, em boa hora, que "a indenização mede-se pela extensão do dano". Logo, em regra, é indiferente a situação jurídica do ofensor, pois " a maior gravidade da falta não influi sobre a indenização, a qual, só se medirá pela extensão do dano causado"20.

Logo, em que pese as divergências doutrinárias a esse respeito, o propósito central da responsabilidade civil é o de remover um dano, restituindo a vítima à mesma situação em que encontraria caso o evento danoso não tivesse se verificado. A reversão do eventual enriquecimento percebido pelo ofensor é apenas uma repercussão indireta da obrigação de indenizar: na medida em que o lesante é obrigado a restaurar o desfalque patrimonial do lesado, esse valor acabará sendo abatido do seu patrimônio.

Em todo caso, o que provoca a reação do ordenamento jurídico, nessa seara, é a perda ou diminuição verificada no patrimônio do lesado, e não o possível aumento ou vantagem advindo ao patrimônio do lesante. O elo que cria o dever de indenizar se justifica em função dos prejuízos suportados pela vítima, em consequência de um fato atribuível ao autor do fato danoso.

Decidir a que título o interventor deverá restituir ao titular do direito o lucro obtido através da indevida intromissão na esfera jurídica deste dependerá da posição adotada acerca dos requisitos e funções da responsabilidade civil e do enriquecimento sem causa. Essa constatação permite verificar que a celeuma em torno do enquadramento dogmático do lucro da intervenção deriva, na realidade, de uma controvérsia mais abrangente, relativa aos contornos dos dois institutos.

Não por acaso, a corrente que propugna que a solução para o lucro da intervenção se dê por intermédio da responsabilidade civil, tende a defender a expansão das funções de tal instituto para além da função basilar reparatória:

\footnotetext{
${ }^{20}$ ALVIM, Agostinho. Da inexecução das obrigações e suas consequências. $3^{\mathrm{a}}$ ed. atual. Rio de Janeiro; São Paulo: Editora Jurídica e Universitária, 1965. p. 197.
} 
A sua ideia seria já, porventura, a de que só assim o procedimento do infrator teria uma sanção adequada e se preveniriam futuras infrações; e é sobretudo a partir daí - da acentuação, cada vez mais nítida na doutrina moderna, de uma função sancionatória e preventiva da responsabilidade civil ao lado da sua tradicional função reparadora ou reintegrativa - que se defende a obrigação de restituir o lucro ${ }^{21}$.

Objetivamente, há duas alternativas para resolver o problema do lucro da intervenção no âmbito da responsabilidade civil: (i) admitir uma nova fórmula de cálculo da indenização (o chamado "terceiro método"), ou (ii) aceitar a chamada "indenização punitiva", a qual contemplaria o grau de culpa do ofensor e os benefícios econômicos por ele auferidos para determinar o valor a ser pago à vítima sob a rubrica de indenização.

Tais propostas, no entanto, além de gerar diversas distorções e incoerências sistemáticas, e serem ostensivamente contrárias às disposições legais pertinentes, não têm o condão de solucionar o problema eficazmente, como se passará a demonstrar.

\subsection{O Terceiro Método de Cálculo da Indenização}

A Lei de Propriedade Industrial ( ${ }^{\circ}$ 9279/96) prevê, no art. 210, um triplo método de cálculo dos lucros cessantes devidos em casos de exploração não autorizada de direitos relativos a marcas, patentes e desenhos industriais, estipulando, ademais, a preponderância do critério mais benéfico ao titular do direito violado, nos seguintes termos:

Art. 210. Os lucros cessantes serão determinados pelo critério mais favorável ao prejudicado, dentre os seguintes:

I - os benefícios que o prejudicado teria auferido se a violação não tivesse ocorrido; ou

II - os benefícios que foram auferidos pelo autor da violação do direito; ou

\footnotetext{
${ }^{21}$ PEREIRA COELHO, Francisco Manuel. O enriquecimento e o dano [1970]. Coimbra: Almedina, 1999. p. 33.
} 
III - a remuneração que o autor da violação teria pago ao titular do direito violado pela concessão de uma licença que lhe permitisse legalmente explorar o bem.

O inciso II da sobredita norma encerra a única hipótese no ordenamento jurídico brasileiro que prevê a utilização dos benefícios auferidos pelo autor da violação como parâmetro para a quantificação da reparação civil, a excepcionar o art. 402 do Código Civil ${ }^{22}$.

Gisela Sampaio ${ }^{23}$ atribui a utilização do lucro da intervenção como parâmetro para aferição dos lucros cessantes a uma "ficção atécnica adotada pelo legislador brasileiro", devido à dificuldade quase insuperável de se provar a extensão dos lucros cessantes na hipótese de violação de marca ou modelo de utilidade, com a legítima finalidade de não deixar o inventor da patente sem reparação, assegurando-se, dessa forma, a eficácia da função dissuasiva da responsabilidade civil.

Com efeito, a forma de apuração dos lucros cessantes prevista no art. 210, II, da Lei n ${ }^{0}$ 9279/96 encerra uma ficção jurídica, na medida em que parte da presunção ilusória de que o lesado teria auferido um ganho equivalente àquele obtido pelo interventor, apesar de o processo produtivo, margem de lucro, e estratégias de marketing de cada qual serem diferentes.

Por outro lado, reconhece-se que a determinação do quantum da reparação pecuniária a partir da esfera jurídica do interventor é incompatível com a fórmula da equivalência patrimonial, que norteia a reparação por danos de natureza material, inclusive lucros cessantes:

Já a doutrina, como foi visto, manifesta um enorme estranhamento, especialmente por conta da sua incompatibilidade com a fórmula da equivalência que deve, tanto quanto possível, orientar a reparação por dano patrimonial, e também assim a dos lucros cessantes, ainda que por estimativa. A função dos lucros cessantes na responsabilidade civil é flagrantemente reparatória, não sendo, portanto, recomendável introduzir na aferição desta faceta do dano patrimonial critérios que sequer são afeitos à responsabilidade civil, sob pena de a reparação dos lucros

\footnotetext{
22 "Art. 402. Salvo as exceções expressamente previstas em lei, as perdas e danos devidas ao credor abrangem, além do que ele efetivamente perdeu, o que razoavelmente deixou de lucrar."

${ }^{23}$ GUEDES, Gisela Sampaio da Cruz. Lucros Cessantes: do bom-senso ao postulado normativo da razoabilidade. São Paulo: Editora Revista dos Tribunais, 2011. p. 221.
} 
cessantes se transformar numa verdadeira caixa de Pandora que, embora incite a curiosidade, é sempre preferível não tocar ${ }^{24}$.

Fica nítido, portanto, que a previsão, no texto legal, de pagamento de “indenização" baseada no proveito econômico obtido pelo transgressor da patente não tem a aptidão de ilidir a verdadeira natureza jurídica dessa verba, que configura restituição. A propósito, é pertinente invocar as lições de Sérgio Savi e Gisela Sampaio:

É por isso que se questiona o lugar sistemático dessa obrigação de restituir o lucro obtido pelo interventor em razão da violação de um direito de propriedade industrial. Afinal "não parece estar em causa uma indenização de um dano de acordo com os moldes tradicionais, mas, antes, a restituição de um lucro ${ }^{25}$.

Mesmo em sede de direitos de propriedade industrial, o triplo método de cálculo da indenização deve ser "destrinchado", separando o remédio apropriado para cada situação. Quando a vítima do ato violador do direito de propriedade industrial requerer a "indenização" dos "lucros cessantes" baseada nos lucros do interventor, não obstante a terminologia, estar-se-á diante de uma restituição que deveria observar as regras do enriquecimento sem causa ${ }^{26}$.

A partir desse exame, bem se vê que a obrigação de restituir o lucro da intervenção - e isso é inegável - é muito mais consentânea com a disciplina do enriquecimento sem causa (no caso enriquecimento por intervenção) do que, propriamente, com a responsabilidade civil, razão pela qual, em princípio, o lucro do ofensor só pode ser utilizado como parâmetro para aferição dos lucros cessantes com muitas ressalvas e, de preferência, apenas quando o legislador assim o estabelecer. Do contrário, a utilização arbitrária desse critério desvirtuaria a própria função da responsabilidade civil; a indenização dos lucros cessantes não cumpriria a sua função reparatória de repor o patrimônio do lesado ao estado anterior ao evento danoso ${ }^{27}$.

\footnotetext{
${ }^{24}$ GUEDES, 2011, p. 223.

${ }^{25}$ SAVI, Sérgio. Responsabilidade civil e enriquecimento sem causa: o lucro da intervenção. São Paulo: Atlas, 2012. p. 86-87.

${ }^{26}$ Ibid., p. 88 .

${ }^{27}$ GUEDES, 2011, p. 223.
} 
Com efeito, ainda que por "equívoco normativo" 28 o art. 210, II, da Lei $n^{0}$ 9279/96 reflete a consagração da proposição teórica que identifica relevância no lucro auferido pelo interventor para a delimitação da indenização a ser paga em favor da vítima do dano injusto.

Embora se trate de regra excepcional, aplicável apenas às hipóteses de violação de marcas e patentes, parte da doutrina entende que a consideração das vantagens auferidas pelo autor de conduta danosa traduziria um terceiro método de cálculo do dano patrimonial, ao lado dos critérios tradicionais do dano (ou empobrecimento) real e patrimonial:

A expressão faz carreira na mais recente doutrina alemã (...). O 'terceiro método' de cálculo do dano permitiria ao lesado exigir ao lesante a restituição do lucro obtido por este, e seria assim distinto, quer do 'primeiro método' (indenização do dano concreto, de acordo com a 'diferença' no patrimônio do lesado), quer do 'segundo método' (indenização do dano 'real', no sentido definido supra) ${ }^{29}$.

Todavia, considerando que a responsabilidade civil tem por desígnio, no ordenamento jurídico brasileiro, recompor um desfalque produzido no patrimônio da vítima, a doutrina dos três métodos "não é a forma adequada de tratamento dogmático das intervenções sobre bens imateriais" ${ }^{30}$.

Tampouco deve ser aplicada aludida doutrina para equacionar ingerências sobre bens materiais, tendo em vista que a função própria da responsabilidade é a de remover um dano e seja qual for a concepção que se adote sobre o conceito de dano, "não há dúvida de que ele se determina a partir da esfera do lesão e não da esfera do lesante, pelo que um método de

\footnotetext{
28 Nesse sentido: Tal opção legislativa poderia ser interpretada meramente como equívoco normativo, mas há que se registrar que a solução adotada pela legislação nacional no âmbito da disciplina das hipóteses de violações a direitos de propriedade industrial não traduz autêntica peculiaridade da experiência brasileira. SCHREIBER, Anderson; SILVA, Rodrigo da Guia. Lucro da Intervenção: Perspectivas de Qualificação e Quantificação In: Direito Civil: Estudos - Coletânea do XV Encontro dos Grupos de Pesquisa - IBDCIVIL. São Paulo: Blucher, 2018. p. 182.

${ }^{29}$ PEREIRA COELHO, 1999, p. 32.

${ }^{30}$ LEITÃO, Luís Manuel Teles de Menezes. O enriquecimento sem causa no direito civil: estudo dogmático da configuração unitária do instituto, face à contraposição entre as diferentes categorias do enriquecimento sem causa. Coimbra: Almedina, 2005. p. 696.
} 
cálculo do dano que parta da esfera do lesante representa no fundo a mera dispensa desse requisito" 31.

A despeito disso, cumpre ressaltar a expressiva tendência, na jurisprudência brasileira, de associação imediata entre lucro da intervenção e lucros cessantes. A decisão da Terceira Turma do Superior Tribunal de Justiça no REsp 1.335.624/RJ ${ }^{32}$ é emblemática dessa confusão dogmática, que propugna a inclusão das vantagens auferidas pelo interventor no processo de quantificação da indenização devida à vítima de um dano injusto.

O caso concreto analisado pela Corte remonta à veiculação de campanha publicitária do refrigerante Coca-Cola, na qual figuravam de exjogadores da Seleção Brasileira de Futebol trajando "cópia disfarçada" do uniforme da seleção brasileira masculina de futebol utilizado na conquista da Copa do Mundo de 1994. A Confederação Brasileira de Futebol (CBF) ingressou com ação de obrigação de fazer e não fazer cumulada com pedido indenizatório, em face de Coca Cola Indústrias Ltda.

Na primeira instância, o juízo sentenciante julgou o pleito autoral parcialmente procedente, obrigando a ré a retirar a peça publicitária de circulação. A CBF apelou, pugnando pela reforma da sentença para determinar o pagamento de indenização por danos morais e materiais, assim como a "devolução do lucro com enriquecimento ilícito".

A $15^{\mathrm{a}}$ Câmara Cível do Tribunal de Justiça do Estado do Rio de Janeiro, sem fazer referência expressa ao pleito de "devolução do lucro com enriquecimento ilícito", deu provimento parcial ao recurso da CBF, condenando a Coca Cola Indústrias ao pagamento de lucros cessantes à CBF pelo "uso indevido, por imitação, de uniforme e distintivo de propriedade da autora da ação".

\footnotetext{
${ }^{31}$ Ibid., p. 696.

${ }^{32}$ BRASIL. STJ. Terceira Turma, REsp $n^{\circ}$ 1.335.624/RJ, Min. Rel. Ricardo Villas Bôas Cueva, j. 05.12.2013.
} 
Ainda, no tocante ao quantum indenizatório, concluiu-se que o mesmo deveria "corresponder ao que a autora/segunda apelante poderia ter ganhado, caso tivesse autorizado o uso de seu uniforme e distintivo, tendose em conta o que suas demais patrocinadoras lhe pagaram e considerando apenas o período em que efetivamente houve divulgação da propaganda".

Após a interposição de recurso especial pela Coca-Cola Indústrias, a Terceira Turma do STJ, por unanimidade, negou provimento ao recurso, asseverando que o caso em comento não cuidava de lucros cessantes meramente presumidos, mas de "evidente prejuízo, pois, segundo a prática comercial usual, somente patrocinadores oficiais obtêm autorização para a utilização da imagem da seleção brasileira de futebol".

Essa decisão retrata com clareza a problemática de transplantar o lucro da intervenção para a seara da responsabilidade civil, incorporando-o à delimitação do dano indenizável.

Com efeito, ao se vislumbrar na exploração desautorizada de bens ou direitos alheios um dano material ao titular, considera-se que tal dano corresponde à perda de remuneração usualmente devida pela celebração do contrato.

Nesse diapasão, equacionar a problemática do lucro da intervenção por intermédio do pagamento de indenização em favor do titular do direito equivaleria a admitir a existência ficta de um contrato entre o interventor e o proprietário “lesado". Isso porque, conforme leciona MENEZES LEITÃO:

A concepção de que a não obtenção da remuneração corrente no mercado constituiria um lucro cessante do titular do direito industrial representa uma ficção conceitual já que, não tendo sido celebrado qualquer contrato, o titular não deixou de adquirir nenhuma remuneração em consequência da lesão, não tendo assim sofrido danos. ${ }^{33}$

No entanto, a mera condenação ao pagamento de lucros cessantes como sucedâneo da obrigação de restituir o lucro auferido, redundaria no

\footnotetext{
${ }^{33}$ MENEZES LEITÃO, 2005, P. 708.
} 
pagamento da mesma contrapartida que teria sido inicialmente devida, caso o interventor tivesse se empenhado em obter, e logrado, o consentimento do titular por uma via lícita.

Afinal, se o objeto da indenização equivale ao valor de mercado do bem jurídico usurpado, é mais vantajoso, do ponto de vista econômico, explorar o bem pertencente à esfera jurídica alheia e aguardar a reação do titular, contando com as incertezas inerentes ao processo judicial, do que realizar o pagamento da contraprestação $a b$ initio.

Esse fenômeno ficou conhecido, no direito no Direito NorteAmericano como contractual by-pass, expressão que foi traduzida por JÚLIO MANUEL VIEIRA GOMES como curto circuito do contrato $^{34}$, e que designa a perda generalizada da eficácia das vias negociais de aquisição de direitos.

Com efeito, caso o enriquecido seja condenado a pagar, a título de indenização, o mesmo valor da contraprestação que seria acordada com o titular, por ocasião da celebração do contrato, então, ao menos do ponto de vista econômico, a violação terá valido a pena. O interventor não corre o risco de não chegar a um acordo com o titular, e tampouco tem algo a perder ao explorar o bem jurídico sem a permissão do seu proprietário, pois, na pior das hipóteses, a verba devida a título de indenização não ultrapassará o valor de mercado que teria sido pago, a priori, para a aquisição daquela utilidade.

A responsabilidade civil funcionaria, então, como uma espécie de atalho, toda vez em que o valor da indenização não ultrapassasse o que a vítima ganharia, normalmente, se a contratação tivesse sido concluída. O instrumento ressarcitório se convolaria numa espécie de expropriação, em benefício privado, realizada a preço de mercado $^{35}$.

Foi justamente o que ocorreu nos autos da Apelação Cível $\mathrm{n}^{\mathrm{o}}$ 20.737/00, julgada pela $9^{a}$ Câmara Cível do Tribunal de Justiça do Rio de

\footnotetext{
${ }^{34}$ GOMES, Júlio Manuel Vieira. O conceito de enriquecimento, o enriquecimento forçado e os vários paradigmas do enriquecimento sem causa. Porto: Universidade Católica Portuguesa, 1998. p. 755.

${ }^{35}$ Cf. GALLO, Paollo. Pene private e responsabilità civile. Milano: Giuffrè, p. 71 e ss.
} 
Janeiro, em que famosa atriz pleiteava indenização diante da publicação, não autorizada, em jornal de grande circulação, de sua foto nua, extraída de cena de minissérie por ela protagonizada e veiculada em canal de televisão. O parâmetro adotado para fixar o valor da reparação a título de dano material foi a quantia que seria cobrada pela atriz para posar nua nas mesmas circunstâncias noticiadas pelo jornal. ${ }^{36}$ Referido entendimento, contudo, não merece prosperar, uma vez que acaba por legitimar a expropriação de bens ao preço de mercado, além de não retirar do patrimônio do agente, de forma cabal, os ganhos por ele amealhados.

Nesse sentido, a responsabilidade civil não desponta, ao menos de forma isolada, como sanção capaz de dissuadir a usurpação de bens e direitos alheios. Portanto, depositar exclusivamente nesse instituto a reversão do problema do lucro da intervenção implicará na perda de relevância da manifestação de vontade dos titulares de posições jurídicas ativas, privandoos do controle sobre os bens integrantes do seu patrimônio.

\subsection{Distinção Conceitual entre Lucro da Intervenção e Lucros Cessantes}

Do ponto de vista estrutural, o fato gerador da indenização por lucros cessantes é a interrupção da cadeia de acontecimentos que, no curso ordinário, culminaria na geração de um proveito econômico para a vítima. Os lucros cessantes, encerram, portanto, uma expectativa de ganho futuro, dentro de um juízo de probabilidade objetiva ${ }^{37}$.

Nesse sentido, o suporte fático do lucro cessante é composto pela constatação de que o evento danoso obstaculizou a percepção de benefícios econômicos pela vítima. Logo, o ganho financeiro esperado não chega a se

\footnotetext{
${ }^{36}$ BRASIL. TJ-RJ. $9^{\mathrm{a}}$ CC, Rel. Des. Marcus Tullus Alves, $A C$ 20.737/00, j. 13.3.2001.

${ }^{37}$ Nesse sentido: "O critério mais acertado para se computar o lucro cessante, nessa linha estaria em condicioná-lo a uma probabilidade objetiva, em decorrência do desenvolvimento normal dos acontecimentos, observando-se, sempre, as circunstâncias peculiares ao caso concreto". THOMPSON FLORES LENZ, Carlos Eduardo. Considerações sobre a indenização por lucros cessantes. Revista do Ministério Público. n 34/90-93, Porto Alegre: Nova Fase, 1995. p. 93.
} 
concretizar, mas, ao revés, se frustra. Consequentemente, para aferir a extensão do lucro cessante indenizável, faz-se necessário reconstruir o que LARENZ $^{38}$ denomina de "curso hipotético do dano" (hypothetischen schandensverlauf), a fim de verificar qual teria sido a evolução patrimonial provável do prejudicado, caso o evento danoso não houvesse ocorrido.

O lucro da intervenção, por sua vez, não representa um resultado econômico hipotético, cuja realização restou frustrada pela ingerência danosa de um agente externo. Pelo contrário, a iniciativa do interventor é a própria causa propulsora da geração do lucro.

Além disso, enquanto o lucro cessante deriva de uma projeção futura, o lucro da intervenção é concretamente acrescido ao patrimônio do interventor. A figura do interventor, portanto, não se confunde com a do ofensor, pois enquanto este último impede a produção de ganhos financeiros, o primeiro é responsável por incorporar bens ou direitos alheios a um processo produtivo que desagua na geração de renda.

Sob esse prisma, os "lucros cessantes", faceta do dano patrimonial composta pelo que a vítima "razoavelmente deixou de lucrar" se apartam do lucro da intervenção, pois (i) traduzem uma expectativa de ganho provável, sem existência concreta e (ii) sua produção é obstruída por um fator externo, atribuível ao ofensor.

Por essa razão é que transplantar o problema do lucro da intervenção para o domínio da responsabilidade civil reclama a utilização de diversas ficções jurídicas, com significativa repercussão no aspecto pragmático.

Com efeito, em muitos casos o interventor explora bens alheios de forma que o próprio titular jamais teria cogitado utilizar. Nesse particular, pressupor que o titular do direito teria consentido com a exploração econômica, pelo interventor, do bem integrante do seu patrimônio, pode gerar

\footnotetext{
${ }^{38}$ LARENZ, Karl. Derecho de obligaciones. t. I. Jaime Santos Briz (Trad.)., Madrid: Editorial Revista de Derecho Privado, 1958. p. 208.
} 
distorções, hipótese bem ilustrada pelo caso Edward vs. Lee's Administrator $^{39}$, narrado por JÚLIO MANUEL VIEIRA GOMES:

\begin{abstract}
Tratou-se de uma situação em que o agente tinha descoberto, na sua propriedade, a entrada de uma caverna que continha numerosas estalactites e estalagmites, bem como um rio subterrâneo. A referida caverna converteu-se numa atração turística que justificou a construção de um hotel. Contudo, cerca de um terço da gruta estendia-se por uma propriedade limítrofe. O tribunal norte-americano que decidiu este caso considerou adequado atribuir ao titular do prédio vizinho um terço do lucro líquido obtido. Torna-se desnecessário sublinhar que este resultado não poderia ser alcançado no continente através do mecanismo da responsabilidade civil: o proprietário não parece, efetivamente, ter sofrido qualquer dano. A passagem subterrânea de turistas pela sua propriedade não era, obviamente, suscetível de a deteriorar e de implicar a sua diminuição de valor. Poder-se-á, é certo, invocar o lucro cessante, a importância que o proprietário deixou de receber pela sua permissão; contudo, e para lá da dificuldade em estabelecer o seu valor, sobretudo numa situação tão atípica como esta em que não existe um preço normal no mercado, bem poderia suceder que o proprietário do prédio vizinho não estivesse nunca disposto, por preço algum, a conceder a referida permissão. Nesta última hipótese, e acordo com a teoria da diferença, não se pode afirmar a existência de um dano.
\end{abstract}

Se por um lado, no caso relatado acima, o proprietário do imóvel limítrofe teve parte do seu terreno explorado sem sua autorização, devido à construção de uma passagem subterrânea, por outro lado, não se pode afirmar que suportou um dano emergente em decorrência dessa intromissão. Nesta hipótese, admitir a indenização por lucros cessantes seria temerário tendo em vista que, se não fosse pela ingerência não autorizada sobre a sua propriedade, o dono do terreno lindeiro jamais teria obtido qualquer proveito pela exploração turística da caverna.

Afinal, diante do caráter inédito e da originalidade da empreitada, não seria razoável supor que o proprietário teria optado por aproveitar o bem de forma igualmente lucrativa. O titular do terreno jamais teria logrado extrair do seu imóvel um proveito econômico dessa magnitude, o qual foi proporcionado, ao revés, por obra do interventor.

\footnotetext{
3996 S.W. (2) 1028 (1936). Sobre o caso, v. ZIFF, Bruce. The great onyx cave cases - a microhistory. Northern Kentucky Law Review. Highland Heights, v. 40, n.1, p. 1-48, 2013.
} 
Considerando, ainda, que um dos filtros da indenização por lucros cessantes é o prognóstico de probabilidade (e não mera possibilidade) do benefício econômico que seria obtido pela vítima caso a violação não tivesse ocorrido, a aplicação isolada da responsabilidade civil a esse caso não surtiria o pagamento de indenização em favor do proprietário.

Nessa linha, CALOS NELSON KONDER afirma que:

No entanto, haveria nesse caso uma confusão conceitual, já que não há como afirmar que tenha sido a ação do interventor que tenha impedido o titular do direito de ganhar algo que seria razoável reputar que ele ganharia. Ao contrário, no mais dos casos só houve algum tipo de lucro por que o interventor decidiu agir, pois sem isso o titular do direito não teria auferido lucro algum ${ }^{40}$.

A restituição do lucro, portanto, não encontra sua base de sustentação na responsabilidade civil, mas no enriquecimento sem causa, com fundamento no princípio do conteúdo da destinação jurídica dos bens e direitos, que garante ao titular todo o proveito econômico que aquele bem é capaz de gerar.

É importante ressaltar a necessidade de se discriminar entre o lucro decorrente da iniciativa e dos bens titulados pelo próprio interventor, daquele que deriva da usurpação de situações jurídicas subjetivas alheias, pois apenas esse último será objeto da obrigação de restituir.

Além das situações em que o titular jamais teria conferido ao bem integrante do seu patrimônio a destinação que lhe fora atribuída pelo interventor, o que basta para descartar a qualificação dos proventos derivados dessa atividade como um "lucro cessante" que o lesado teria deixado de perceber, pode-se ainda vislumbrar casos em que, por questões de ordem ética ou moral, o titular do direito jamais teria anuído com a sua cessão.

Tal circunstância é bem retratada pelo caso do cantor Caetano Veloso: o artista, que sempre recusou convites para figurar em propagandas de bebida

\footnotetext{
${ }^{40}$ KONDER, Carlos Nelson. Dificuldades de uma Abordagem Unitária do Lucro da Intervenção. In: Revista de Direito Civil Contemporâneo. no 4, v. 13, out.-dez./2017, p. 237.
} 
alcoólica, aceitou participar de evento denominado "Heineken Concerts", promovido pela Cervejaria Kaiser. Preocupado em evitar qualquer apologia ao consumo de cerveja, fez incluir no contrato com a produtora do evento uma cláusula proibindo expressamente a vinculação publicitária de sua imagem à cerveja Heineken. A despeito disso, a Cervejaria Kaiser fez divulgar no jornal Folha de São Paulo seis páginas de material publicitário promovendo a cerveja, sendo uma delas dedicada exclusivamente à veiculação da imagem de Caetano.

Diante disso, o artista ingressou com uma ação indenizatória ${ }^{41}$, postulando, além da compensação por danos morais, ressarcimento por lucros cessantes. É evidente, no entanto, que não se pode falar em "lucro cessante" nessa circunstância, em que o cantor afirmou categoricamente na inicial da ação indenizatória que não teria concordado em ceder a utilização da sua imagem para a Heineken por preço algum.

A vantagem que a Heineken obteve ao usurpar a imagem do cantor para promover o seu produto, apesar da vedação contratual expressa, não corresponde apenas às despesas poupadas, devido à ausência de contrapartida pela utilização do direito de imagem. É provável que a associação indevida da imagem de Caetano com a cerveja Heineken, como se o cantor endossasse a qualidade da bebida e incentivasse o seu consumo, se traduza em um incremento das vendas.

Nesse cenário, não seria lícito permitir que a fabricante de cervejas ficasse com o proveito econômico, derivado da exploração de um direito (imagem), cujo uso não adquiriu licitamente. O problema, evidentemente, reside no nexo de causalidade. Em termos práticos, seria muito difícil - senão impossível - comprovar em que extensão o aumento de vendas pode ser atribuído à veiculação da imagem de Caetano, tendo em vista que a comercialização da cerveja pode sofrer influência de diversos outros fatores.

\footnotetext{
${ }^{41}$ Processo $n^{\circ}$ 1997.001.015086-6, movido perante a 39 ${ }^{\text {a }}$ Vara Cível da Comarca da Capital do Rio de Janeiro. A ação foi extinta em 1997, em razão de acordo celebrado entre as partes.
} 
Nesse caso, portanto, pode-se admitir que o lucro da intervenção e os hipotéticos lucros cessantes se equivalham na prática, conquanto os conceitos jamais se imiscuam. Pertinente, a propósito, a crítica formulada por CLÁUDIO MICHELON JR. ao comentar a hipótese de intervenção sobre direitos da personalidade:

O valor total da restituição devida nesses casos é normalmente quantificado pelos tribunais como sendo o valor daquilo que o interventor-enriquecido deveria ter despendido para obter a autorização que tornaria a intervenção legítima (com causa). Essa forma de quantificação tem a vantagem de ser mais fácil de aferir em casos concretos. Em que pese essa vantagem, a jurisprudência não vai bem ao utilizar esse critério, uma vez que o enriquecimento sem causa não é uma forma de ressarcir lucros cessantes, mas sim uma forma de restituir ao dono da imagem os lucros que foram obtidos a partir da sua imagem. (...) a forma de quantificação do enriquecimento não deve tomar em conta aquilo que o 'empobrecido' deixou de ganhar, mas sim o que o enriquecido lucrou a partir da imagem de outrem ${ }^{42}$.

Diante dessas considerações, a tendência observada na práxis judicial brasileira, de associação imediata entre lucro da intervenção e lucros cessantes deve ser veementemente repelida, promovendo-se a correta qualificação e distinção funcional entre os regimes jurídicos obrigacionais, conforme o perfil funcional promovido em cada caso.

Afinal, é necessário reconhecer que a "pretensão ao lucro da intervenção e a pretensão indenizatória são (...) coisas fundamentalmente diferentes" $"$. A gênese da confusão pragmática parece estar na semelhante “função genérica" dos dois institutos, que visam a repor um equilíbrio que se rompeu ${ }^{44}$ e, neste sentido, corrigir a distribuição natural da riqueza segundo exigências de justiça.

À guisa de conclusão, o lucro do ofensor só deve, em princípio, ser utilizado como parâmetro para aferição dos lucros cessantes quando o

\footnotetext{
${ }^{42}$ MICHELON Jr., 2007, p. 203-204.

${ }^{43}$ No original: "Der Anspruch auf den Eingriffserwerb und der Schadenersatzanspruch sind (...) grundverschiedene Dinge". SCHULZ, Fritz. System der Rechte auf den Eingriffserwerb. Archiv für die civilistische Praxis, 105. Bd., H. 1, 1909. p. 457.

${ }^{44}$ OSTENDORF, Heribert. Der Vermogensbegriff im Bereicherunsgrund Schadensrecht. BB, 1973. p. 822 e segs apud GOMES, Júlio Manuel Vieira. In: $O$ conceito de enriquecimento, o enriquecimento forçado e os vários paradigmas do enriquecimento sem causa. Porto: Universidade Católica Portuguesa, 1998. p. 249.
} 
legislador expressamente o estabelecer, a exemplo do art. 210, II, da Lei de Propriedade Industrial, que tem o propósito de contornar a extrema dificuldade do titular da patente violada demonstrar a extensão dos seus lucros cessantes. Tal solução não deveria ser aplicada por analogia em outros domínios, sob pena de desvirtuar a função própria da responsabilidade civil.

\subsection{Indenização Punitiva}

A despeito da ontológica função reparatória da responsabilidade civil - ou compensatória, nos casos em que a lesão atinge uma situação jurídica subjetiva extrapatrimonial ${ }^{45}$-, assiste-se, nas últimas décadas, à tentativa de se lhe atribuir pretensa função punitivo-pedagógica. A partir dessa perspectiva, abre-se a possibilidade de majorar o valor da indenização, a fim de impor ao ofensor uma constrição patrimonial suficientemente relevante para desencorajar a reincidência delitiva, pelo próprio agente e por terceiros que temeriam incorrer na mesma sanção no futuro.

A análise do cabimento dessa proposição normativa interessa ao presente trabalho, pois há quem vislumbre na introdução de critérios punitivos de quantificação da verba indenizatória - tais como o grau de culpa do ofensor e sua capacidade econômica - um meio indireto de redirecionar o eventual lucro obtido com o ato ilícito para o patrimônio da vítima:

A second group of situations where it would be useful to apply private sanctions takes place whenever someone enriches himself as a consequence of his wrongful behavior. (...) No one could be allowed to enrich himself at the expenses of another; otherwise everybody would be induced to infringe the rights of other

\footnotetext{
${ }^{45}$ A indenização por dano moral não ostenta função reparatória, uma vez que o dano à dignidade da pessoa humana é insuscetível de avaliação pecuniária; o montante em dinheiro conferido a título de dano moral visa, apenas, a servir de lenitivo para mitigar, de alguma forma, o dano sofrido. Esta é a posição de Maria Celina Bodin de Moraes: Aquele que sofre um dano moral deve ter direito a uma satisfação de cunho compensatório. Diz-se compensação, pois o dano moral não é propriamente indenizável; 'indenizar' é a palavra que provem do latim, 'in dene', que significa devolver (o patrimônio) ao estado anterior, ou seja, eliminar o prejuízo e suas consequências - o que, evidentemente, não é possível no caso de uma lesão de ordem extrapatrimonial. Prefere-se, assim, dizer que o dano moral é compensável, embora o próprio texto constitucional, em seu artigo $5^{\circ}, \mathrm{X}$, se refira à indenização do dano moral. MORAES, Maria Celina Bodin de. Danos à pessoa humana: uma leitura civil-constitucional dos danos morais. Rio de Janeiro: Renovar, 2003. p. 145.
} 
peoples in order to gain the difference between the detriment inflicted and the enrichment obtained ${ }^{46}$.

Os ilícitos lucrativos seriam, nesse sentido, o grande fundamento para que ao lado de uma verba que leve em conta a estrita violação aos direitos da vítima, outra seja aduzida com o objetivo de sancionar o agente ${ }^{47}$.

Na mesma linha, a National Conference of Comissioners of Uniform State Laws, ao aprovar o Model Punitive Damages Act, incluiu dentre os fatores a serem levados em consideração para a decisão acerca do valor da indenização punitiva "qualquer lucro ou ganho obtido pelo réu com seu ato ilícito, em excesso daquilo de que o réu provavelmente será despojado nesta ou outras ações de indenização ou restituição ajuizadas contra ele"48.

De início, há que se distinguir entre, de um lado, a necessidade de evitar que atos lesivos se transformem em um 'bom negócio' do ponto de vista econômico, e, de outro, a necessidade de efetivamente impor uma pena privada ao ofensor, diante da reprovabilidade de sua conduta.

A fim de impedir que a exploração inadvertida de bens e direitos alheios se converta em fonte de benefícios ao interventor, basta um remédio que assegure a restituição do patrimônio do enriquecido ao estado em que se encontraria caso o fato gerador do locupletamento não houvesse ocorrido.

A princípio, a reversão do enriquecimento ilícito em favor do titular do direito, a quem estavam reservadas as utilidades econômicas de seus bens, é medida suficiente para reconduzir o patrimônio do ofensor ao status quo anterior ao ilícito ${ }^{49}$. Esse remédio impede que o interventor conserve em seu

\footnotetext{
${ }^{46}$ GALLO, Paolo. Punitive damages in Italy?. Disponível em: $<$ http://www.jus.unitn.it/cardozo/review/TOrts/Gallo-1997/gallo.htm>. Acesso em: 17 nov. 2018. ${ }^{47}$ LEVY, Daniel de Andrade. Responsabilidade civil: de um direito dos danos a um direito das condutas lesivas. São Paulo: Atlas, 2012. p. 115.

${ }^{48}$ No original: "any profit or gain, obtained by the defendant through the wrongful conduct, in excess of that likely to be divested by this and any other actions against the defendant for compensatory damages or restitution."

${ }^{49}$ A rigor, o interventor não retorna exatamente à mesma situação em que estaria caso não tivesse perpetrado a ingerência, pois no lucro da intervenção está embutido também o produto do trabalho próprio do interventor e de seus investimentos. Logo, caso o lucro fosse integralmente restituído ao lesado, o enriquecido ficaria em situação pior do que a que estaria se não tivesse realizado a
} 
patrimônio as vantagens pecuniárias originadas da ingerência, sem, outrossim, relegar o interventor a situação pior àquela em que estaria caso não tivesse explorado o bem jurídico alheio.

O resultado da aplicação do remédio restitutório, portanto, é a neutralidade. Suprimindo os incentivos financeiros proporcionados pela atuação antijurídica, a atratividade financeira da intervenção deixará de existir, desestimulando esse tipo de prática.

\begin{abstract}
Nesse sentido, a obrigação de restituir traduz-se, a bem da verdade, no próprio inverso ou avesso da ideia de indenização: não é na esfera patrimonial do lesado, mas na do lesante que se restabelece a situação que existiria sem a intervenção ilícita. Assim é que, ao se estender a obrigação de restituir a todo o lucro causado pela intromissão, reconduz-se o patrimônio do enriquecido à situação próxima a que estaria se não tivesse praticado a ação que lhe trouxe a vantagem ${ }^{50}$.
\end{abstract}

Noutro giro, punição só haverá, a rigor, caso o valor da condenação imposta ao ofensor seja superior ao somatório dos benefícios provenientes do ato ilícito praticado. Na seara sancionatória, o que suscita a reação do ordenamento é a censurabilidade da conduta do réu e, por conseguinte, o objetivo da penalização não é a recomposição pura e simples do patrimônio do ofensor ao status quo ante. A punição, ao revés, deve assegurar que o ofensor seja reconduzido a uma situação mais gravosa do que aquela em que estaria caso a intervenção não tivesse ocorrido.

Em regra, as condutas cuja gravidade é tida pelo legislador como merecedoras de sanção autônoma, independentemente da produção de qualquer prejuízo, são tipificadas no âmbito do direito penal e administrativo, cuja finalidade precípua é punir o agente do ato ilícito.

O direito sancionatório é norteado por princípios próprios como a tipicidade, a legalidade, a anterioridade, a subsidiariedade, a intransponibilidade da pena, etc. Além disso, os procedimentos destinados a

intromissão na esfera alheia, sendo possível falar na manutenção de um caráter punitivo na restituição, ainda que residual.

${ }^{50}$ GUEDES, 2011, p. 198-199. 
penalizar condutas ilícitas contam com uma série de garantias e recursos, que visam a assegurar ao acusado o mais abrangente exercício da ampla defesa e do contraditório.

A responsabilidade civil e o enriquecimento sem causa, por outro lado, só são chamados a atuar em razão do efeito constatado no patrimônio da vítima e do ofensor, respectivamente, em decorrência de um ato ilícito. A conduta antijurídica não tem relevância de per si, mas apenas em função das suas repercussões patrimoniais.

O art. 944 do Código Civil consagra o princípio da equivalência entre dano e reparação. Portanto, malgrado se pretenda encobrir, sob o manto do dano moral, funções diametralmente opostas - pune-se e compensa-se sob a mesma rubrica - é evidente que a parcela da condenação que ultrapassa a extensão do dano encerra autêntica pena privada.

Desse modo, é necessário perquirir se estão reunidos todos os requisitos para cominação de uma pena privada ao autor do ato ilícito, nas hipóteses de exploração desautorizada de bens e direitos de terceiros, que constituem o suporte fático do lucro da intervenção.

A inclusão, no valor global da indenização, de uma parcela não destacada destinada a penalizar o ofensor reflete uma peculiaridade da experiência brasileira, decorrente da importação irrefletida do instituto do punitive damages dos países de common law, sem a análise acerca da compatibilidade e da própria necessidade desta figura em nosso ordenamento.

Embora o caráter punitivo da indenização por dano moral seja uma realidade na doutrina ${ }^{51} \mathrm{e}$ na jurisprudência pátrias, não se pode aderir acriticamente a este movimento. É preciso reconhecer "o perigo da importação de práticas incompatíveis com o espirito do ordenamento

\footnotetext{
${ }^{51}$ A favor da tese do caráter punitivo da indenização por danos morais estão, entre outros, Caio Mário da Silva Pereira, Carlos Edison do Rêgo Monteiro Filho, Antônio Jeová Santos, Silvio Rodrigues, Carlos Alberto Bittar, Yussef Said Cahalid, Sérgio Severo e Sérgio Cavalieri Filho, etc.
} 
receptor" 52 , sob pena de se criar figuras híbridas e sem amparo legal, a exemplo do que se passa, justamente, com o alegado caráter punitivo do dano moral $^{53}$.

De início, cumpre ressaltar que não há no ordenamento jurídico brasileiro uma teoria geral das penas privadas, que se reflita em um tratamento uniforme da matéria. Com efeito, a sistematização de um regime geral encontra óbice na imensa disparidade de hipóteses abrangidas sob essa designação ${ }^{54}$.

Em que pese as dificuldades para a construção de uma formulação abrangente sobre o tema, a Constituição Federal fixa os requisitos mínimos para a instituição de penas, ao estabelecer que "não há crime sem lei anterior que o defina, nem pena sem prévia cominação legal" (art. 5, XXXIX, $\mathrm{CRFB} / 88)$.

Nessa esteira, a positivação da sanção pecuniária através de lei em sentido estrito é imprescindível à sua imposição. Logo, a doutrina e a jurisprudência, ainda que majoritárias, jamais poderão legitimar a atribuição de um viés punitivo à reparação, devendo as sugestões nesse sentido ser tomadas, no máximo, como de lege ferenda. Afinal, sendo necessário para esse desiderato a existência de previsão legal autorizativa, conclui-se que o ordenamento jurídico brasileiro, de lege lata, não acolhe os punitive damages como título autônomo de indenização.

A despeito da ausência de alicerces no direito positivo, os tribunais brasileiros têm insistido em empregar critérios de quantificação de natureza punitiva, à margem de indicação legislativa expressa ou tácita, no afã de

\footnotetext{
${ }^{52}$ MOREIRA, José Carlos Barbosa. O processo penal norte-americano e sua influência. Revista de Direito Renovar. v. 18, p. 54. set./dez. 2000.

${ }^{53}$ TERRA, 2015a, p. 409.

${ }^{54}$ Pode-se arrolar, à guisa de exemplo (i) os arts. 939 e 940, do Código Civil, que sancionam a cobrança indevida de dívida, respectivamente, antes do seu vencimento ou em valor superior ao devido; (ii) as sanções pecuniárias no condomínio edilício pelo descumprimento dos deveres dos condôminos (art. 1.336, § $2^{\circ}$ e art. 1.337, CC), além das sanções de cunho não pecuniário, tais como (iii) a revogação da doação por ingratidão do donatário (art. 557, CC); (iv) a exclusão da sucessão hereditária por indignidade (art. 1.814, CC) e (v) a exclusão de integrante de associação por justa causa ou motivo grave.
} 
justificar indenizações mais elevadas para casos em que o prejuízo gerado pela conduta reiterada, e até mesmo maliciosa do ofensor, não é relevante a ponto de evitar a repetição do ilícito.

A aparente insuficiência dos institutos tradicionais de tutela induziu a jurisprudência a desenvolver mecanismo de quantificação empírico, baseado em critérios dissociados da entidade do dano, tais como a conduta do ofensor ou sua capacidade econômica, fatores que não influenciam na extensão ou na intensidade do prejuízo moral. Essa corrente, mesmo quando se propõe a observar a vítima do dano, concentra-se não em sua projeção pessoal, mas econômica, sob a égide da capacidade econômica da vítima ${ }^{55}$.

A consequência dessa concepção pretoriana que utiliza a capacidade econômica da vítima como parâmetro para aferir o limite da verba compensatória devida é que as vítimas menos abastadas acabam por receber uma compensação inferior por lesões à sua dignidade, devido ao receio de que a responsabilidade civil se convole em fonte de ascensão social do lesado.

Isso ocorre porque as decisões judicias que condenam o autor do ato ilícito ao pagamento de danos morais punitivos, mencionam, de maneira reiterada, a proibição do enriquecimento sem causa como importante limite à fixação do quantum compensatório ${ }^{56}$, em flagrante violação ao princípio da isonomia:

A imprópria invocação do princípio do enriquecimento sem causa na fase de cálculo do dano tem levado os tribunais a estipular, em lesões semelhantes, indenizações menores para pessoas economicamente menos favorecidas. É grave a violação que daí resulta ao princípio da isonomia, consagrado no art. $5^{\circ}$, caput, da Constituição de 1988. A repercussão de uma certa lesão à personalidade de uma

\footnotetext{
${ }^{55}$ TEPEDINO, Gustavo; SCHREIBER, Anderson. As penas privadas no direito brasileiro. In. GALDINO, Flávio; SARMENTO, Daniel (Org.). Direitos Fundamentais: estudos em homenagem ao Professor Ricardo Lobo Torres. Rio de Janeiro: Renovar, 2006.

${ }^{56} \mathrm{Em}$ que pese o grau de subjetivismo que envolve o tema da fixação da reparação, vez que não existem critérios determinados a fixos para a quantificação do dano moral, reiteradamente tem-se pronunciado esta Corte no sentido de que a reparação do dano não pode vir a constituir-se em enriquecimento indevido. Mas, de outro lado, também, há de ser fixada em montante que desestimule o ofensor a repetir o cometimento do ilícito. BRASIL. STJ. $3^{\text {a }}$ T., Rel Min. Castro Filho, Resp 445858/SP, j. 29.11.2005.
} 
pessoa não pode ser considerada menor, por ser mais reduzida a sua capacidade econômica ${ }^{57}$.

Tais decisões parecem ignorar, todavia, que a atribuição de função punitiva ao dano moral promove, tout court, o locupletamento do lesado. Ora, conferir à compensação um plus, que não guarda qualquer relação com a dimensão do dano e tampouco com as suas consequências, e que também não se fundamenta em qualquer título jurídico que o justifique, promove, inquestionavelmente, o ilegítimo incremento patrimonial da vítima.

Logo, a cláusula geral de vedação ao enriquecimento sem causa (art. 884 , CC) resta necessariamente violada quando da cominação de uma “indenização punitiva”, inclusive porque a pena não reverte em favor do Poder Público, titular do poder de punir, mas sim da vítima, que não tem qualquer legítima justificativa para enriquecer-se com esta punição.

Tal preocupação com o locupletamento ilícito não existiria desde que a compensação se adstringisse ao dano moral efetivamente sofrido, pois a causa da indenização é o próprio dano.

O método caótico de quantificação consolidado pela jurisprudência colide frontalmente com a tábua axiológica da Constituição de 1988, que privilegia nitidamente os valores extrapatrimoniais ${ }^{58}$ e assegura, nos incisos $\mathrm{V}$ e $\mathrm{X}$, do art. $5^{\circ}$, a plena compensação do dano moral, cuja extensão independe do status social da vítima.

Nesse particular, é necessário que os critérios de quantificação da reparação convirjam para a dimensão da lesão e suas repercussões na pessoa

\footnotetext{
${ }^{57}$ SCHREIBER, Anderson. Direito Civil e Constituição. São Paulo: Atlas, 2013. p. 181.

${ }^{58}$ A constatação e o reiterado alerta acerca da necessidade de se reinterpretar o direito civil à luz dos novos valores constitucionais vêm da doutrina de Gustavo Tepedino. Cf. Premissas Metodológicas para a Constitucionalização do Direito Civil in Temas de Direito Civil, Rio de Janeiro: Renovar 1999, p. 22: "Trata-se, em uma palavra, de estabelecer novos parâmetros para a definição de ordem pública, relendo o direito civil à luz da Constituição, de maneira a privilegiar, insista-se ainda uma vez, os valores não patrimoniais e, em particular, a dignidade de pessoa humana, o desenvolviment da sua personalidade, os direitos sociais e a justiça distributiva, para cujo atendimento deve se voltar a iniciativa econômica privada e as situações jurídicas patrimoniais."
} 
da vítima, a fim de que a verba reparatória alcance a singularidade de quem sofreu a lesão:

(...) as condições pessoais da vítima, desde que se revelem aspectos de seu patrimônio moral, deverão ser cuidadosamente sopesadas para que a reparação possa alcançar a singularidade de quem as sofreu, sob a égide do princípio da isonomia substancial ${ }^{59}$.

Nessa linha de intelecção, MARIA CELINA BODIN DE MORAES acusa a incoerência de se admitir, concomitantemente, na seara reparatória, punição e arbítrio judicial, além de assinalar para o risco de mercantilização das relações existenciais implicado nesta metodologia:

De nada adianta clamar por moderação e equilíbrio na fixação do quantum indenizatório quando o sistema que se veio delineado aceita a coexistência de duas regras, antagônicas por princípio, no âmbito da reparação de danos morais: a punição, de um lado, e o arbítrio do juiz, de outro. Nesses casos, em geral a função punitiva 'corre solta', não tendo qualquer significação no que tange a um suposto caráter pedagógico ou preventivo. Por outro lado, representa, não há como negar, um forte incentivo à malícia, além de gerar a mercantilização das relações existenciais $^{60}$.

Os problemas decorrentes da atribuição de caráter punitivo ao dano moral, apontados pela sobredita autora, podem ser sintetizados da seguinte forma $^{61}$ : (i) uma vez que não prevista em lei, a indenização punitiva implicaria em punição sem prévia cominação legal, conferindo um cheque em branco para o juiz cível ferir o princípio da tipicidade (nullum crimen, nulla poena sine lege); (ii) vários atos geradores de dano moral também são crimes, o que acarretaria bis in idem, especialmente com a previsão de sanção pecuniária no direito penal (Lei $n^{\circ} 9.714 / 98$ ); (iii) tramitando na vara cível, a ação segue os mecanismos processuais e recursais do direito processual civil, sem as garantias típicas do procedimento penal; (iv) o efeito punitivo é mitigado no âmbito civil porque nem sempre o responsável é o culpado

\footnotetext{
${ }^{59}$ BODIN DE MORAES, 2003, p. 173.

${ }^{60}$ BODIN DE MORAES, 2003, p. 261.

${ }^{61}$ Ibid., p. 193-264.
} 
(como nos casos de seguro de dano) e, nestes casos, o verdadeiro culpado não será punido.

Ademais, o fato de a atribuição de caráter punitivo ao dano moral derivar de uma construção jurisprudencial difusa, sem supedâneo na legislação sobre o tema, possui, ainda, implicações em outras garantias constitucionais, como o contraditório e ampla defesa (art. 5\%, LV, $\mathrm{CRFB} / 88)^{62}$. Na prática, as condenações não discriminam os danos punitivos da quantia destinada a compensar a vítima, impedindo que os litigantes impugnem especificamente os respectivos fundamentos em sede recursal.

A propósito, convém invocar a pertinente crítica de ANDERSON SCHREIBER:

O resultado é que as decisões judiciais tratam de forma unitária quantias atribuídas a títulos inteiramente diversos, fundados em fatos e argumentos distintos. Tornase impossível, no cenário brasileiro, separar no valor da condenação a parcela concedida a título de compensação do dano e aquela que se pretende atribuir à vítima a título de punição do ofensor. Há, nisto, violação flagrante ao direito de ampla defesa do causador do dano e limitação ao contraditório em sede de recurso, já que se inviabiliza a discussão acerca da legalidade e conveniência da punição, cuja extensão nem chega a ficar clara ${ }^{63}$.

Nesse compasso, a jurisprudência, além de avocar para si arbítrio que a lei não lhe confere, mantem as partes na mais profunda ignorância, não lhes revelando o valor da pena e o valor da compensação, a obstar qualquer discussão acerca da legalidade e extensão da punição em grau de recurso.

Por fim, cabe registrar que a admissão de danos punitivos em nosso sistema malfere o princípio da segurança jurídica, pois o autor da ação, vítima do dano moral, parece participar de uma loteria forense, em que o reconhecimento do seu direito à indenização bem como o montante

\footnotetext{
62 "LV - aos litigantes, em processo judicial ou administrativo, e aos acusados em geral são assegurados o contraditório e ampla defesa, com os meios e recursos a ela inerentes;"

63 SCHREIBER, Anderson. Arbitramento do dano moral no novo Código Civil. In: Revista Trimestral de Direito Civil. vol. 10, Rio de Janeiro: Padma, 2002, p. 3-24.
} 
compensatório dependerão, sobretudo, da pré-compreensão ${ }^{64}$ do juiz e do seu senso particular de justiça.

Apesar das contundentes razões acima apontadas aconselharem que a condenação ao pagamento de danos punitivos seja expurgada da prática forense, a possibilidade de a atuação antijurídica resultar lucrativa para o interventor continua a agredir o mais comezinho senso de justiça.

Tendo em vista que uma das funções que a atribuição de viés punitivo à responsabilidade civil se propõe a desempenhar é a de retirar do patrimônio do ofensor os lucros porventura auferidos por meio da conduta danosa, o abandono dessa concepção equivocada do remédio ressarcitório deve ser acompanhado da identificação de uma solução funcionalmente equivalente dentro do ordenamento positivo.

Afinal, o debate sobre as alternativas civis à tutela ressarcitória surgiu com a primordial finalidade de restituir credibilidade ao sistema jurídico, reafirmando sua capacidade de coibir o abuso de poder econômico. O problema é que a válvula de escape criada por doutrina e jurisprudência (importação dos punitive damages) além de caminhar na contramão da tendência evolutiva da responsabilidade civil - que se dirige rumo à libertação do propósito inculpador, isto é, da relevância do elemento subjetivo -, implicou no sacrifício de diversos outros valores e princípios constitucionais.

Nesse contexto, o enriquecimento sem causa, fonte autônoma de obrigações, prevista no artigo 884 do Código Civil, exsurge como instituto vocacionado a suprir essa função no caso do lucro da intervenção. O instituto implementa a remoção do incremento patrimonial obtido por intervenção, sem autorização, na situação jurídica subjetiva da vítima. Nessa seara, pouco importam as mutações no patrimônio daquele cuja situação jurídica

\footnotetext{
${ }^{64}$ A pré-compreensão consiste na assunção originária de sentido, isto é, em uma pré-disposição do intérprete de entender o texto e os eventos de uma determinada forma, a partir de certo ponto de vista. Sobre o tema, confira-se PERLINGIERI, Pietro. O Direito Civil na Legalidade Constitucional. Rio de Janeiro: Renovar, 2008. p. 607.
} 
fundamentou o locupletamento alheio, mas apenas o incremento patrimonial do enriquecido.

O referido instrumento não possui escopo punitivo, tampouco se impõe como uma sanção ao enriquecido. O remédio restitutório apenas visa a corrigir um desvio na destinação da utilidade econômica de um direito, redirecionando-o para o patrimônio do seu titular. Trata-se de um mecanismo que tutela o interesse do credor da obrigação de restituir à apropriação de tudo aquilo que represente aproveitamento não autorizado de bens ou outros valores da sua esfera jurídica.

O próximo capítulo se dedicará a evidenciar a correta leitura dos requisitos para a configuração do enriquecimento sem causa, a fim de estabelecer a aptidão do instituto para solucionar as fattispecie reunidas sob o rótulo de lucro da intervenção. 


\section{CAPÍTULO 2 - REQUISITOS PARA A CONFIGURAÇÃO DO ENRIQUECIMENTO SEM CAUSA}

Em todos os sistemas jurídicos existe uma tensão entre regras de atribuição patrimonial e regras de justiça na atribuição patrimonial (regras que regulam a justa atribuição de bens).

Em alguns casos, conquanto o ordenamento confira eficácia ao ato de disposição patrimonial, permitindo que a transferência da titularidade do direito se aperfeiçoe, faz surgir uma obrigação de restituir, por entender que inexiste justificativa para esse deslocamento de riqueza. Em outros, a ordem jurídica reputa que a gravidade do defeito no ato de atribuição é tão grave, que sequer permite que surta efeitos jurídicos, seja por inexistência, invalidade ou ineficácia ${ }^{65}$.

O art. 884 do Código Civil é a fonte primária da obrigação de restituir em nosso ordenamento, razão pela qual convém analisar sua dicção a fim de verificar os quais exigências condicionam a aplicação da cláusula geral de enriquecimento sem causa, instituída pelo aludido dispositivo legal, verbis:

Art. 884. Aquele que, sem justa causa, se enriquecer à custa de outrem, será obrigado a restituir o indevidamente auferido, feita a atualização dos valores monetários.

À luz desse enunciado, depreende-se que o suporte fático do instituto é composto de (i) um enriquecimento ${ }^{66}$ (ii) para o qual não haja justa causa e (iii) que se produza a partir da esfera jurídica de um terceiro (“à custa de outrem").

\footnotetext{
${ }^{65}$ Nesse sentido, o enunciado 188, da III Jornada de Direito Civil: "A existência de negócio jurídico válido e eficaz é, em regra, uma justa causa para o enriquecimento."

${ }^{66}$ Como indica Antunes Varela, o enriquecimento pode decorrer de aumento do ativo, como também de diminuição do passivo, ou mesmo de poupança de despesa. ANTUNES VARELA, João de Matos. Das Obrigações em Geral. v. I, $10^{\mathrm{a}}$ ed., Coimbra: Almedina, 2005. p. 481.
} 
A estes requisitos "positivos", soma-se, ainda, um pressuposto negativo, colocado pelo art. 886 do Código Civil:

Art. 886. Não caberá a restituição por enriquecimento, se a lei conferir ao lesado outros meios para se ressarcir do prejuízo sofrido.

Portanto, para que a pretensão de reversão do enriquecimento se revista de eficácia, é necessário constatar, ainda, a inexistência absoluta de "outros meios" jurídicos (além da actio in rem verso) através dos quais o "lesado" possa alcançar o "ressarcimento" do "prejuizo sofrido". O referido dispositivo regula as relações entre as regras que regem o enriquecimento sem causa e as regras que regem outras fontes de relações obrigacionais, instituindo o requisito da "subsidiariedade".

Com isso, o remédio restitutório mostra-se como a ultima ratio para o saneamento de deslocamentos patrimoniais cuja existência seja de alguma forma autônoma a quaisquer requisitos essenciais à responsabilidade civil ${ }^{67}$. A intenção do legislador é de que a ação de enriquecimento sem causa seja o último recurso que o empobrecido possa utilizar.

De início, a análise conjunta dos dispositivos revela uma incoerência relevante. Enquanto o art. 884 menciona apenas a existência de um acréscimo patrimonial com supedâneo na esfera jurídica de outrem, sem fazer qualquer alusão à necessidade de um “empobrecimento" correlato do titular do direito, o art. 886, por outro lado, sugere que o credor da obrigação de restituir tenha, necessariamente, suportado um prejuízo em decorrência do locupletamento alheio às suas custas.

A atecnia normativa das expressões - "lesado" e "prejuizo sofrido" empregadas no art. 886 revelam que o próprio legislador não soube distinguir

\footnotetext{
${ }^{67}$ KONDER, Carlos Nelson; SAAR, Patrick. A relativização do Duplo Limite e da Subsidiariedade nas Ações por Enriquecimento sem Causa. In: TEPEDIO, Gustavo et al. (Coord.). Da dogmática à efetividade do Direito Civil: Anais do Congresso Internacional de Direito Civil Constitucional - IV Congresso do IBDCIVIL. Belo Horizonte: Fórum, 2017. p. 155.
} 
adequadamente as hipóteses ensejadoras do dever de indenizar daquelas que suscitam a obrigação de restituir o lucro:

A expressão trazida na nova lei civil é imprecisa, uma vez que pode dar azo à confusão o instituto do enriquecimento sem causa com a responsabilidade civil.

A junção das expressões "lesado" e "prejuízo", contidas no mencionado art. 886, subsidia o enganado raciocínio de que a ação de enriquecimento possui cunho indenizatório, quando, na verdade, é uma ação de restituição, com requisitos distintos da ação de indenização ${ }^{68}$.

Sem dúvida, esse dispositivo é o grande responsável pela "mentalidade aquiliana" que impera em matéria de enriquecimento sem causa no Brasil, e que se reflete nas teorias do deslocamento patrimonial e do duplo limite do enriquecimento sem causa.

De acordo com a teoria do duplo limite, o valor da obrigação de restituir não equivaleria sempre ao enriquecimento patrimonial, acrescido ao patrimônio do interventor-enriquecido, mas se sujeitaria a um segundo limite, o do dano do empobrecido, caso este fosse inferior:

Como veremos, de acordo com a chamada teoria do duplo limite, o quantum da actio in rem verso é guiado por dois parâmetros. Melhor dizendo, ele será, entre dois critérios, o menor. São estes critérios o enriquecimento patrimonial, de um lado, e de outro, o 'empobrecimento' real ${ }^{69}$.

Esta é a opinião, por exemplo, de AGOSTINHO AlVIM:

Com efeito, se o enriquecimento for superior ao empobrecimento, que acontece? Suponha-se: o enriquecimento doze e empobrecimento dez. A medida será então o empobrecimento, porque, de outra maneira, o empobrecido passaria a enriquecido, recebendo além do necessário para o reequilíbrio do seu patrimônio. O ponto de vista que nos parece acertado é o dos autores que mandam que se considere o menor valor $^{70}$.

\footnotetext{
${ }^{68}$ NANNI, Giovanni Ettore. Enriquecimento sem causa: de acordo com o novo Código Civil. São Paulo: Saraiva, 2004. p. 250.

${ }^{69}$ KONDER, 2005, p.385.

${ }^{70}$ ALVIM, Agostinho. Do enriquecimento sem causa. RT 259/3-36, São Paulo: Ed. RT, mai./ 1957, p. 19.
} 
Esta linha de raciocínio possui raízes na ideia de que a vantagem obtida à custa da esfera jurídica de outrem não seria suficiente, por si só, para legitimar o exercício da ação de in rem verso se não houver, em contrapartida, uma perda sofrida pelo demandante. A partir disso, parte da doutrina ${ }^{71}$ vislumbra a necessidade de um "nexo causal" entre o enriquecimento e um suposto empobrecimento suportado pelo credor da obrigação de restituir:

Essencial, ainda, que exista uma relação de causa e efeito entre o benefício de uma parte e o empobrecimento de outra. Apenas o nexo de causalidade pode explicar o nascimento da obrigação de quem se beneficiou consistente em reparar quem perdeu. Para o estabelecimento do dever de restituir, mister que se estabeleça essa relação ${ }^{72}$.

A exigência desse fato - empobrecimento - como elemento do suporte fático do enriquecimento sem causa está ligada a uma determinada précompreensão do instituto segundo a qual o enriquecimento sem causa é gerado por um deslocamento de valor entre dois patrimônios (em moldes similares aos do instituto do pagamento indevido $)^{73}$.

No entanto, o instituto não deve ser utilizado para tentar equacionar um dano verificado no patrimônio do titular do direito, função reservada à responsabilidade civil, mas sim para extrair do patrimônio do enriquecido o que foi indevidamente acrescido.

A origem dessa concepção se encontra na "Teoria Unitária do Deslocamento Patrimonial", desenvolvida por SAVIGNY ${ }^{74}$, segundo a qual

\footnotetext{
${ }^{71}$ Entre outros tantos, veja-se ALVIM, Agostinho. Do enriquecimento sem causa, Revista Forense, v. 173, fasc 651-652, set.-out. 1957. p. 59;

ASTONE, Francesco. L'arrichimento senza causa. Milano: Giuffrè, 1999. p. 85 ss.;

SCHLESINGER, Piero. Arrichimento (azione di), Novissimo digesto italiano. Torino: Utet, 1958. v.1., p. 1007;

TRABUCCHI, Alberto. Arrichimento (azione di). Enciclopedia del diritto. Milano: Giuffrè, 1957. v.3., p. 72;

VALE FERREIRA, José G. do. Enriquecimento sem causa, 3. ed. Belo Horizonte: Livraria Oscar Nicolau, s/d., p. 140.

${ }^{72}$ CASTRO NEVES, José Roberto de. O enriquecimento sem causa: dimensão atual do princípio do direito civil. In: BODIN DE MORAES, Maria Celina (Coord.). Princípios de direito civil contemporâneo. Rio de Janeiro: Renovar, 2006. p. 185-220.

${ }^{73}$ MICHELON Jr., 2007, p. 206.

${ }^{74}$ SAVIGNY. System des heutigen romischen Rechts. Berlin: Veit; Scientia Verlag Aalen, 1849, 1981. p. 526-527 apud MENEZES LEITÃO, Luíz Manuel Teles de. O enriquecimento sem causa no novo Código Civil brasileiro: estudo dogmático da configuração unitária do instituto, face à
} 
para o surgimento da pretensão de enriquecimento sem causa seriam necessários dois requisitos: (i) um deslocamento patrimonial direto entre duas pessoas, produzindo enriquecimento em uma e o correlativo empobrecimento na outra e (ii) ausência de causa jurídica para esse deslocamento patrimonial ${ }^{75}$.

Baseada nessa teoria, parte da doutrina pátria passou a interpretar, a partir do requisito de que o enriquecimento tenha seu suporte na situação jurídica subjetiva de outrem ("à custa de outrem" na dicção do art. 884) como sinônimo da ocorrência de um "deslocamento patrimonial”.

Em outras palavras, apesar de inexistir qualquer regra expressa nesse sentido no Código Civil Brasileiro, passou-se a exigir que aquilo que produz o enriquecimento tenha, obrigatoriamente, pertencido anteriormente ao patrimônio daquele que exige a restituição.

Trata-se, portanto, de uma concepção modelada sobre a repetição de indébito, que não é, contudo, a única hipótese existente de enriquecimento sem causa. A predominância dessa interpretação pode ter sido agravada, em nosso ordenamento, pelo fato de o Código Civil de 1916 não disciplinar o enriquecimento sem causa como fonte autônoma de obrigações, limitando-se a prever exemplos de sua ocorrência e, entre eles, a tratar de forma detalhada do pagamento indevido (Código Civil de 1916, arts. 964 e seguintes).

Os adeptos da teoria do deslocamento patrimonial parecem partir de uma perspectiva estática segundo a qual "nada se cria nem se destrói”. Nessa linha de intelecção, se um sujeito enriquece às expensas de um outro, a lógica sugeriria que o outro sofresse uma perda simétrica. Essa concepção é falha por descurar que o enriquecimento pode ser fruto de criação autônoma, baseada na apropriação indevida de bens ou diretos alheios, e,

contraposição entre as diferentes categorias do enriquecimento sem causa. Coimbra: Almedina, 2005. p. 25.

${ }^{75}$ MENEZES LEITÃO, Luís Manuel Teles de. Direito das Obrigações: introdução, da constituição das obrigações. v. I. 8. ed. Coimbra: Almedina, 2009. p. 412-413. 
consequentemente, sua geração não implica necessariamente na subtração de algo que existia no patrimônio que fundamentou o locupletamento.

Note-se que o emprego da palavra restituição não significa que o interventor deverá devolver algo que já existia no patrimônio do titular do direito antes da intervenção. A restituição também é do patrimônio do interventor ao status quo ante.

A bem da verdade, caso o empobrecimento seja encarado como pressuposto e limite da obrigação de restituir, esta careceria de genuína autonomia, convertendo-se, na prática, numa espécie de forma menor e anômala de responsabilidade civil.

\begin{abstract}
Daí parecem naturais construções como as que colocam na base do enriquecimento sem causa uma noção de deslocação patrimonial, de fluxo e refluxo de valores, ou aquelas que exigem um empobrecimento concomitante ao enriquecimento verificado. Se, contudo, não houver o cuidado de precisar que a deslocação patrimonial não supõe a identidade exata entre o perdido por um e o obtido pelo outro, e muito menos requer que se trate de uma coisa corpórea que se desloca fisicamente de um patrimônio para outro, ou senão se tiver plena consciência de que o famoso empobrecimento não corresponde ao conceito de dano em sede de responsabilidade civil, mas é porventura muito mais amplo, corre-se o risco de atrofiar consideravelmente o enriquecimento sem causa e de o converter num 'parente pobre', numa caricatura ou imitação da responsabilidade civil ${ }^{76}$.
\end{abstract}

Assim, o acolhimento da teoria do duplo limite, com a limitação da obrigação de restituir ao empobrecimento do titular do direito, acabaria por limitar o escopo de atuação do enriquecimento sem causa, condicionando sua aplicação à verificação de um 'dano'. Sintomaticamente, os caudatários da teoria do duplo limite do enriquecimento sem causa, acabam chegando à conclusão de que o ordenamento jurídico apresenta uma lacuna ${ }^{77}$ com relação

\footnotetext{
${ }^{76}$ GOMES, 1998, p. 225.

${ }^{77}$ Segundo Norberto Bobbio, existe uma lacuna quando falta em determinado ordenamento uma regra a que o juiz possa recorrer para solucionar determinada controvérsia. In: BOBBIO, Norberto. Contributi ad um dizionario giuridico. Torino: G. Giappichelli, 1994. p. 90. Ainda segundo Bobbio: "Entende-se também por 'lacuna' a falta não já de uma solução, qualquer que seja ela, mas de uma solução satisfatória, ou, em outras palavras, não já a falta de uma norma, mas a falta de uma norma justa, isto é, de uma norma que se desejaria que existisse, mas que não existe. Uma vez que essas lacunas derivam não da consideração do ordenamento jurídico como ele é, mas da comparação entre ordenamento jurídico como ele é e como deveria ser, foram chamadas de 'ideológicas', para distinguí-las daquelas que eventualmente se encontrassem no ordenamento jurídico como ele é, e que podem chamar de 'reais'. Podemos também enunciar a diferença deste modo: as lacunas
} 
às situações de usurpação antijurídica de situações jurídicas subjetivas alheias:

Mas quando a intervenção não causa dano ao titular do direito ou, causando um dano, o lucro da intervenção excede este dano, então já a questão se torna obscura e difícil.

Parece que, agora, nem o princípio da responsabilidade civil nem o do enriquecimento sem causa podem dar fundamento bastante à pretensão do titular do direito exigir do interventor o enriquecimento que excede o dano, sendo certo, quanto ao primeiro princípio, que a obrigação de indenizar se mede, de um modo geral, pelo dano causado, e, quanto ao segundo, que a obrigação de restituir o enriquecimento sem causa é, ao que se diz, duplamente limitada, pelo enriquecimento e pelo dano. E, assim, estando excluída a aplicação quer do primeiro quer do segundo princípio, o lucro excedente ao dano pertenceria definitivamente ao titular do direito, a qualquer título ${ }^{78}$.

Com efeito, em várias das situações de intervenção antijurídica em bens alheios, o titular do direito não sofre um prejuízo efetivo, embora sua esfera jurídica tenha servido de suporte a um enriquecimento alheio. O merecimento de tutela conferido ao credor da obrigação de restituir decorre não da proteção do seu patrimônio contra mutações patrimoniais injustas, mas do fato de que a ordem jurídica reserva ao titular de situações jurídicas subjetivas a potencialidade de sua exploração econômica:

Em síntese, em todos os sistemas que não remetem ao modelo francês (mas também em outros que simplesmente se distanciaram no ponto), a prova de um dano efetivo e de uma correlação entre benefício e diminuição patrimonial não é necessária: aquilo que por nós é denominado 'dano' é alhures identificado no uso da propriedade, no gozo do direito, na interferência nas proposições patrimoniais alheias, na ingerência, definitiva, na esfera jurídica de um outro sujeito e do desfrutamento de seus recursos ${ }^{79}$.

Portanto, a aceitação da doutrina do duplo limite só seria possível (e mesmo assim para um número limitado de casos) se o "dano" que limita a

\footnotetext{
ideológicas são lacunas de iure condendo (de direito a ser estabelecido), as lacunas reais são de iure conditio (do direito já estabelecido)". In: BOBBIO, Norberto. Teoria do ordenamento jurídico. $10^{\mathrm{a}}$ ed. Trad. Maria Celeste C. J. Santos. Brasília: Universidade de Brasília, 1997. p. 140.

${ }^{78}$ PEREIRA COELHO, 1999, p. 11-12.

${ }^{79}$ ALBANESE, Antonio. Ingiustizia del profitto e arrichimento senza causa. In: Le monografie di Contratto e impresa. Serie diretta de Francesco Galgano, v. 87, Padova: Cedam, 2005. p. 377.
} 
restituição fosse entendido não na acepção que autoriza o manejo de uma ação indenizatória, mas em termos do "conteúdo da destinação econômica" do bem, isto é, da noção de que cabe ao titular de um direito tudo quanto ele seja capaz de render ou produzir.

Assim, eventual rendimento obtido pelo uso desses bens ou direitos “pertence, em princípio, de acordo com o conteúdo da destinação ou afetação (Zuweisungsgehalt) de tais direitos, ao respectivo titular." 80.

Quando o titular se vê privado de bem que efetivamente usava, deixando, assim, de perceber as concretas vantagens por ele proporcionadas, a responsabilidade civil será capaz de ressarcir a lesão sofrida, mas não promoverá a retirada do lucro do patrimônio do ofensor se esse benefício se revelar superior ao dano sofrido pela vítima ${ }^{81}$.

Outras vezes, todavia, a exploração de bens alheios não gera dano indenizável, como se passa na hipótese em que o titular do bem já não o usa e tampouco pretende fazê-lo, a afastar a incidência da responsabilidade civil.

Os exemplos arrolados por ANTUNES VARELA no trecho abaixo são emblemáticos das inúmeras hipóteses de privação do uso em que o titular do direito não estava disposto a utilizar o bem nos moldes em que o interventor o fez, nem lhes dar qualquer outro destino:

Admitamos que o dono da casa onde outrem se instalou indevidamente (por julgála própria) a não teria arrendado em quaisquer circunstâncias; que o dono do cavalo ou do automóvel com que o amigo, utilizando abusivamente o animal ou o veículo, ganhou avultado prêmio numa competição desportiva, não estaria disposto a concorrer a tal prova; que o dono da obra editada, sem a sua autorização, por terceiros não etária inclinado a publicá-la, etc.

Em nenhum desses casos se pode rigorosamente falar numa diminuição do património do dono da coisa e nem sequer na privação dum aumento dele, uma vez que o titular não estava disposto a usar ou fruir da coisa nos termos em que fez o intrometido.

\footnotetext{
${ }^{80}$ VARELA, João de Matos Antunes. Das obrigações em geral. Coimbra: Almedina, 2000. p. 492.

81 TERRA; GUEDES, 2015, p. 13.
} 
$\mathrm{E}$, todavia, não se pode duvidar de que a vantagem patrimonial do beneficiado foi obtida à custo do dono da coisa ${ }^{82}$.

Com efeito, nos exemplos acima reproduzidos, não há que se falar em um lucro cessante, nem dano emergente do proprietário, embora este tenha sido privado do uso e gozo que lhe são assegurados pelo art. 1.228 do Código Civil $^{83}$. Isso porque a mera potencialidade abstrata do uso não constitui interesse jurídico merecedor de tutela, e sua violação não gera, por si só, dano; o interesse jurídico tutelado é aquele, patrimonial ou não, que pode restar violado pela supressão de alguma vantagem específica que poderia ser auferida pelo uso efetivo do bem, e apenas a lesão a interesse juridicamente tutelado configura dano, passível de indenização ${ }^{84}$.

Por essa razão, a expressão 'à custa de outrem', do art. 884 deve ser entendida como "a necessidade de que haja um suporte do enriquecimento por outrem, que se produza um locupletamento à custa alheia, ou seja, com bens jurídicos pertencentes a pessoa diversa" ${ }^{" 5}$, não já como a imprescindibilidade de um correspondente empobrecimento ${ }^{86}$. Nesse sentido, o enunciado $\mathrm{n}^{\mathrm{o}} 35$ da I Jornada de Direito Civil do Conselho da Justiça Federal preconiza que:

A expressão "se enriquecer à custa de outrem" do art. 884 do novo Código Civil não significa, necessariamente, que deverá haver empobrecimento.

Nessa esteira, para o surgimento da pretensão restitutória, basta que a vantagem tenha sido obtida à custa de algum bem ou direito que se encontre na esfera jurídica de outrem e não, necessariamente, do patrimônio de

\footnotetext{
82 VARELA, João de Matos Antunes. Das obrigações em geral. v. 1. $9^{\text {a }}$ ed. Coimbra: Livraria Almedina, 1996. p. 505-506.

83 "Art. 1.228. O proprietário tem a faculdade de usar, gozar e dispor da coisa, e o direito de reavêla do poder de quem quer que injustamente a possua ou detenha".

${ }^{84}$ SCHREIBER, Anderson. Novos Paradigmas da Responsabilidade Civil: da erosão dos filtros da responsabilidade civil à diluição dos danos. São Paulo: Atlas, 2007. p. 102 e ss.

${ }^{85}$ ALMEIDA COSTA, Mário Júlio. Direito das obrigações. $7^{\mathrm{a}}$ ed. Coimbra: Almedina, 1998. p. 446.

${ }^{86}$ TERRA, Aline de Miranda Valverde. Privação do uso: dano ou enriquecimento por intervenção. Revista Eletrônica Direito e Política, Programa de Pós-Graduação Stricto Sensu em Ciência Jurídica da UNIVALI, Itajaí, v. 9, n. 3, $3^{\circ}$ quadrimestre de 2014. Disponível em: $<$ http://www.univali.br/direitoepolitica>. Acesso em: 18 nov. 2018.
} 
outrem, configurando, assim, o nexo de "imputação que justifica que alguém tenha que restituir o enriquecimento que se gerou no seu patrimônio"87.

Nesta perspectiva, para os fins de caracterização de uma obrigação de natureza restitutória, é necessária uma apropriação indébita de uma utilidade que compete a outrem, mas não necessariamente uma verdadeira e própria transferência patrimonial ${ }^{88}$.

Portanto, enquanto em sede de responsabilidade civil, o lesado tem o ônus de provar o benefício econômico de que foi privado em razão da conduta do ofensor (lucros cessantes), na seara do enriquecimento sem causa, que se volta ao desfazimento de uma atribuição patrimonial desprovida de razão legítima, basta que se prove (i) a extensão do lucro obtido pelo ofensor e (ii) o grau de contribuição causal do bem ilicitamente usurpado para a formação do lucro, correspondente, no mínimo, ao valor de mercado.

Rompendo com o tratamento dogmático unitário do enriquecimento sem causa, WALTER WiLBURG ${ }^{89}$ e ERNST VON CAEMMER ${ }^{90}$ passaram a propugnar a divisão do instituto em categorias autônomas e distintas entre si, sujeitas a princípios distintos e a diferentes ordenações sistemáticas. $\mathrm{O}$ instituto passaria a ser bipartido em duas categorias principais: uma relativa a situações de enriquecimento geradas com base numa prestação do empobrecido (enriquecimento por prestação) e outra abrangendo as situações não fundadas em uma prestação (enriquecimento por intervenção):

\footnotetext{
${ }^{87}$ MENEZES LEITÃO, 2005, p. 876.

${ }^{88}$ GALLO, Paolo. Il Codice Civile: comentário - arrichimento senza causa, Art. 2041-2042, Milano: Giuffre, 2003. p. 63.

${ }^{89}$ WILBURG, Walter. Die Lehre von der ungerechtfertigten Bereicherung nach österreuchischem und deutschem Recht. Kritik und Aufbau, Graz, Leuschner \& Lubensky, 1934 apud LEITÃO, Luís Manuel Teles de Menezes. O enriquecimento sem causa no direito civil: estudo dogmático da configuração unitária do instituto, face à contraposição entre as diferentes categorias do enriquecimento sem causa. Coimbra: Almedina, 2005. p.399.

${ }^{90}$ VON CAENNERER, Ernst. Bereicherung and unerlaubte Handlung em HANS DÖLLE, Max Rheinstein; ZWEIGERT, Jobrad (Org.). Fetschrift für Ernst Rabekm I - Rechtsvergleichung und internattionales Privatrecht, Tübingen, Mohr, 1954. p. 333-401 apud LEITÃO, Luís Manuel Teles de Menezes. $O$ enriquecimento sem causa no direito civil: estudo dogmático da configuração unitária do instituto, face à contraposição entre as diferentes categorias do enriquecimento sem causa. Coimbra: Almedina, 2005. p.399.
} 
A doutrina da divisão do instituto rompe completamente com o tratamento dogmático unitário do enriquecimento sem causa, que deixa inclusive de ser considerado como sujeito a princípios comuns ou a uma mesma ordenação sistemática. Efetivamente, de acordo com essa nova concepção, o enriquecimento por prestação passa a ser visto como um anexo do direito dos contratos, inserido no regime da transmissão dos bens, enquanto o enriquecimento por intervenção é visto antes como anexo a um prolongamento da eficácia do direito de propriedade, inserindo-se no âmbito da proteção jurídica dos bens ${ }^{91}$.

Na primeira categoria enquadram-se as hipóteses que envolvem um translado de um patrimônio para o outro, havendo, portanto, um incremento no patrimônio do enriquecido simétrico ao empobrecimento do titular do direito. $O$ enriquecimento sem causa por prestação se caracteriza, normalmente, por uma manifestação volitiva do titular do direito, dirigida à realização de uma determinada finalidade que, no entanto, não pode ser concretizada por meio daquela atribuição patrimonial.

Isso ocorre, por exemplo, quando o solvens realiza um pagamento crendo, erroneamente, estar extinguindo uma obrigação pelo adimplemento, quando, de fato, o fim visado não pode ser atingido, já que a dívida não existe, sendo desprovido de causa o enriquecimento ensejado por esse ato.

Enquanto o enriquecimento por prestação é regulamentado pelos arts. 876 e seguintes do Código Civil brasileiro, MENEZES LEITÃo sustenta que o enriquecimento por intervenção seria mais adequadamente tratado na cláusula geral do art. 884 do Código Civil, para cuja configuração bastaria a “ingerência não autorizada no patrimônio alheio, como sucederá nos casos de uso, consumo, fruição ou disposição de bens alheios"92.

A distinção entre enriquecimento por intervenção e enriquecimento por prestação não é meramente acadêmica, possuindo, outrossim, reflexos de ordem prática na quantificação da obrigação de restituir. Enquanto o enriquecimento por intervenção tem maior eficácia restitutória, tutelando todas as potencialidades econômicas de aproveitamento do bem ou direito, o enriquecimento por prestação enseja, de forma mais limitada, apenas a

\footnotetext{
${ }^{91}$ MENEZES LEITÃO, 2004, p. 26.

${ }^{92}$ Ibid., p. 26-27.
} 
restituição daquilo que migrou entre patrimônios, seja isso um valor pecuniário, um bem ou a contraprestação devida para a utilização daquela utilidade.

Afinal, no enriquecimento por prestação - resultante da migração entre dois patrimônios de direito pessoal, valor pecuniário ou bens - não faz muito sentido que o objeto da translação tenha um valor em relação ao primeiro patrimônio distinto do valor que possui em relação ao segundo ${ }^{93}$. De outro giro, nas hipóteses em que o enriquecimento deriva de uma intervenção não autorizada em bens alheios, deve-se perquirir a contribuição econômica do bem para a geração de lucro dentro do processo produtivo em que foi inserido, exame que depende da destinação econômica concretamente atribuída ao bem pelo interventor.

Em outras palavras, no enriquecimento por intervenção a restituição deve ser medida pela projeção concreta do direito usurpado na situação patrimonial do beneficiário (concepção patrimonial de enriquecimento).

\subsection{Ausência de Justa Causa para o Enriquecimento}

Importa definir, ademais, em que circunstâncias um incremento patrimonial pode ser reputado como desprovido de "justa causa" para fins de atrair a incidência da cláusula geral de vedação ao locupletamento indevido.

Em primeiro lugar, cumpre extremar o "enriquecimento sem causa" do "enriquecimento ilícito", que não são expressões equivalentes, conquanto muitas vezes sejam empregadas como tal. Com efeito, a ausência de causa não se confunde com a ilicitude, embora não raro uma situação concreta preencha simultaneamente os pressupostos da responsabilidade civil e do enriquecimento sem causa.

\footnotetext{
${ }^{93}$ Pode-se, no entanto, vislumbrar duas situações que tornam a delimitação do quantum restitutório mais complexa mesmo nos casos de enriquecimento por prestação: (a) a situação em que o accipiens, por conta de suas decisões de investimento, obteve (ou poderia ter obtido) significativos frutos do valor investido e (b) a situação em que o valor obtido (que está expresso em dinheiro) tenha sofrido decréscimo por desvalorização monetária no período durante . Cf: MICHELON Jr., 2007, p. 240.
} 
$\mathrm{Na}$ teoria do enriquecimento sem causa, o instituto se situa no âmbito da reprovabilidade perante os princípios do sistema, dispensando-se um ato ilícito para configuração das fattispecie abarcadas pelo art. 884. Nesse particular, convém invocar as lições de TERESA NEGREIROS e MÁRIO JÚLIO DE ALMEIDA COSTA:

Como já vimos, o enriquecimento sem causa dispensa a caracterização do fato ilícito, ou antijurídico, bastando que seja reprovável, pelos princípios do sistema. A esta reprovação se dá o nome de inexistência de causa - causa justificativa, causa legítima. À causa não se prestam definições estáticas, uma vez que o seu conceito resulta da dinâmica do ordenamento, dos seus princípios. A inexistência de causa é, portanto, o que determina a ilegitimidade ou a injustiça substancial do enriquecimento. Trata-se de conceitos, por definição, indeterminados, cujo significado varia conforme as circunstâncias de cada caso. É esta indeterminação do conceito de causa legítima ou justificativa, ligada à noção primeira de justiça social, que faz do enriquecimento sem causa um princípio do ordenamento, revestido da amplitude característica dos princípios $^{94}$.

O problema consiste em distinguir, entre as vantagens patrimoniais que uma pessoa pode obter na vida de relação - aquelas que - embora não chegando ao extremo de serem consequências de comportamentos antijurídicos ou fatos ilícitos (que envolveriam uma responsabilidade por danos) - determinam, todavia, uma obrigação de restituição, visto não se encontrarem dotadas de justificação suficiente em face do direito. Quer dizer: reputa-se que o enriquecimento carece de causa, quando o direito o não aprova ou consente, porque não existe uma relação ou um fato que, de acordo com os princípios do sistema jurídico, justifique a deslocação patrimonial; sempre que aproveita, em suma, a pessoa diversa daquela a quem, segundo a lei, deveria beneficiar. Mas ele é apenas ajurídico, no sentido de substancialmente ilegítimo ou injusto, e não formalmente antijurídico ${ }^{95}$.

A acepção do vocábulo "causa”, nesse domínio, não se identifica com a noção de vontade determinante dos contratantes, elemento do negócio jurídico, mas na existência de uma razão justa e um título idôneo para legitimar determinada atribuição patrimonial, que pode derivar de um contrato, um dispositivo legal, ou de uma decisão judicial.

\footnotetext{
${ }^{94}$ NEGREIROS, Teresa. Enriquecimento sem causa: aspectos de sua aplicação no Brasil como um princípio geral de direito In: Revista da Ordem dos Advogados. v. 55, n. 3/757-845, Lisboa: dez./1995, especialmente p. 806-807.

${ }^{95}$ ALMEIDA COSTA, 1998, p. 432-433.
} 
Nesse sentido, o artigo 885 exige, de forma redundante que não haja causa justificadora do enriquecimento, ou seja, que não haja título jurídico, legal ou convencional, a justificar o incremento patrimonial.

A propósito da ausência de causa, SERPA LOPES ensina que:

Sem causa, portanto, diz-se daquele ato ou negócio jurídico desprovido de força aquisitiva do elemento justificativo para a aquisição de um valor. Não se trata, refere R. SASTRE, da causa final ou do motivo determinante do contrato entre as partes, senão de um caso de aquisição não legitimado por nenhum dos atos ou causas pelo Direito reconhecidos como título de aquisição ou de justificação dos direitos subjetivos ${ }^{96}$.

A locução "sem causa" representa, nesse sentido, um conceito jurídico indeterminado, consistente com a opção fundamental do legislador por um modelo de codificação aberto à influência da cultura:

Estamos convencidos de que a subsistência da função originária do princípio ligada, como vimos, ao fortalecimento da equidade em detrimento do formalismo - depende da não definição do conceito de causa, sob pena de lhe ser restringida de tal forma a aplicação que ele deixe de ter a extensão própria aos princípios gerais de direito ${ }^{97}$.

$\mathrm{O}$ art. 884 encerra, portanto, cláusula geral, de textura propositadamente aberta, destinada a nivelar distúrbios patrimoniais e restaurar a isonomia através da reversão de atos de enriquecimento que não encontrem amparo no ordenamento, considerado em sentido amplo, ou seja, quando contrariem os princípios gerais de direito, a lei e as demais fontes normativas.

Não é possível estabelecer uma fórmula unitária para definir as hipóteses em que o enriquecimento deve ser considerado privado de justa causa. Somente diante do caso concreto e dos elementos de prova poderá o

\footnotetext{
${ }^{96}$ LOPES, Miguel Maria de Serpa. Curso de Direito Civil. v. 5. Rio de Janeiro: Freitas Basto, 1961. p. 84.

${ }^{97}$ NEGREIROS, 1995 , p. 810.
} 
julgador determinar se o aporte de benefícios ao patrimônio do enriquecido tem uma justificação ${ }^{98}$.

Por fim, insta salientar que a ausência de título jurídico formal deve ser casuisticamente sopesada com os demais valores relevantes para a delimitação da (in)justiça do enriquecimento.

A configuração do requisito da ausência de justa causa para fins de deflagração do dever de restituir o lucro da intervenção (como, aliás, da generalidade das hipóteses de enriquecimento sem causa) não se perfaz com a mera análise da inexistência de título jurídico em sentido formal e tradicional. Afigura-se imprescindível, ao revés, a promoção do juízo de merecimento de tutela para que se possa concluir sobre a justiça ou injustiça do enriquecimento à luz da legalidade constitucional ${ }^{99}$.

Assim, por exemplo, o Superior Tribunal de Justiça ${ }^{100}$ superou entendimento até então sumulado no âmbito do Tribunal de Justiça do Rio de Janeiro $^{101}$ relativo aos gastos com segurança de condomínios de fato, ou mesmo associações de moradores. A despeito de a instalação de uma guarita com segurança beneficiar todos os moradores daquela rua, gerando-lhes assim, um enriquecimento, a liberdade dos moradores que não quiserem se associar nem contribuir para o rateio de gastos prevaleceu no entendimento dos Ministros. Nesse caso, portanto, não haveria ausência de causa para o enriquecimento, já que há um fato jurídico idôneo a justificar esse enriquecimento, que seria a liberdade de associação.

Desse modo, ainda que careça de justo título em sentido estrito, a situação jurídica do enriquecido pode vir a ser resguardada caso se conclua,

\footnotetext{
${ }^{98}$ SAVI, 2012, p. 62-63.

${ }^{99}$ SCHREIBER; SILVA, 2018, p. 194.

${ }^{100}$ BRASIL. STJ. $2^{\text {a }}$ Seção, REsp 1.439.163/SP, rel. Min. Ricardo Villas Bôas Cueva, rel. p/ acórdão Min. Marco Buzzi, j. 11.03.2015, DJe 22.05.2015.

101 Súmula TJRJ 79: "Em respeito ao princípio que veda o enriquecimento sem causa, as associações de moradores podem exigir dos não associados, em igualdade de condições com os associados, que concorram para o custeio dos serviços por elas efetivamente prestados e que sejam do interesse comum dos moradores da localidade." Referência: Uniformização de Jurisprudência n. 2004.018.00012 na Apelação Cível no 2004.001.13327, rel. des. Sergio Cavalieri Filho, j. 04.04.2005, votação por maioria, registro de acórdão em 15.07.2005.
} 
diante das circunstâncias do caso concreto, que satisfatoriamente promove os princípios e valores do ordenamento ${ }^{102}$.

102 SILVA, Rodrigo da Guia. Contornos do enriquecimento sem causa e da responsabilidade civil, estudo a partir da diferença entre lucro da intervenção e lucros cessantes. Civilistica.com, a. 5, n. 2, p. 17, 2016. 


\section{CAPÍTULO 3 - A SUBSIDIARIEDADE DO ENRIQUECIMENTO SEM CAUSA}

Conforme exposto, as hipóteses de ingerência não autorizada em bens alheios, com a obtenção de um lucro que exceda o dano produzido, possuem a peculiaridade de preencher, ao mesmo tempo, os pressupostos da responsabilidade civil e do enriquecimento sem causa.

No entanto, diante do requisito da subsidiariedade do remédio restitutório, consagrado no art. 886, do Código Civil, cabe perscrutar se a incidência da responsabilidade civil em uma hipótese concreta eliminaria por completo a possibilidade de manejo da ação de enriquecimento, ou, ao revés, se é possível manejar ambas as pretensões concomitantemente, em atenção às respectivas finalidades.

Com efeito, prevalecendo a primeira tese, de que presentes os pressupostos da responsabilidade civil, afasta-se a possibilidade de o "lesadoempobrecido" demandar a restituição do acréscimo patrimonial auferido pelo “ofensor-interventor”, a ação de enriquecimento sem causa deixaria de ser uma solução viável para a problemática do lucro da intervenção.

De acordo com esse raciocínio, na ocorrência de uma usurpação ilícita da qual decorra para o intrometido um lucro superior aos prejuízos causados à vítima, o quantum excedente ao dano seria conservado no patrimônio do autor do ato ilícito.

Essa compreensão do postulado da subsidiariedade é posta em xeque pelas diferenças de pressupostos e pela própria diversidade de funções que aparta os institutos da responsabilidade civil do enriquecimento sem causa, pois enquanto o primeiro se concentra na ponderação isolada do patrimônio do lesado, o último regula a migração de bens, direitos ou utilidades econômicas entre dois patrimônios independentes ${ }^{103}$.

\footnotetext{
${ }^{103}$ GUEDES, 2011, p. 209.
} 
Afinal, o fato de o ordenamento jurídico conceder várias ações a partir de uma mesma premissa fática atende ao desejo de que todos os interesses afetados sejam adequadamente protegidos. A necessidade prática de simplificar não justifica a fusão ou a confusão entre os remédios legais oferecidos $^{104}$.

MENEZES LEITÃo reconhece que as pretensões restitutória e reparatória remetem a institutos funcionalmente distintos e não excludentes, que, portanto, podem coexistir em uma mesma situação fática:

[e]sta diferente funcionalidade dos dois institutos parece colocar claramente em causa uma integral subsidiariedade da pretensão de restituição do enriquecimento em relação à pretensão de reparação do dano, atendendo à diferenciação do objeto e, portanto, à sua não sobreposição em ambas as pretensões ${ }^{105}$.

Na visão do autor, ao falar em "outro meio" o art. 474, do Código Civil português - que corresponde ao art. 886 do nosso Código - “(...) apenas estabelece uma subsidiariedade da pretensão de enriquecimento se através de outra disposição o lesado conseguir obter o mesmo resultado (ou um resultado superior) do que aquele que lhe adviria da pretensão de enriquecimento"106.

Não sendo esse o caso, a pretensão de enriquecimento não fica afastada pela verificação cumulativa de uma hipótese de responsabilidade civil. Dito de outro modo: qualquer exceção oponível à pretensão de reparação civil - como a ausência de culpa ou dano - não obsta a procedência da pretensão fundada no enriquecimento por intervenção.

O enunciado $\mathrm{n}^{\mathrm{o}} 36$ da I Jornada de Direito Civil do Conselho da Justiça Federal corrobora essa visão acerca da amplitude da subsidiariedade:

$\mathrm{O}$ art. 886, que versa sobre a subsidiariedade do direito à restituição pelo enriquecimento sem causa, não exclui o direito à restituição do enriquecimento

\footnotetext{
104 ARRUE, Xabier Basozabal. Enriquecimento injustificado por intromision em derecho ajeno. Madrid: Editorial Civitas, 1998. p. 104.

105 MENEZES LEITÃO, Luís Manuel Teles de. O enriquecimento sem causa no direito civil, Coimbra: Almedina, 2005. p. 676.

106 Ibid., p. 676.
} 
nem nos casos em que os meios alternativos conferidos ao lesado para se ressarcir do prejuízo encontram obstáculos de fato ${ }^{107}$.

À luz desse enunciado, a melhor interpretação parece ser a de que o direito à restituição por enriquecimento sem causa não surge quando o enriquecimento puder ser desfeito a partir da aplicação das regras que regulam outros tipos de obrigação.

Assim, por exemplo, se os pressupostos da responsabilidade civil se verificam e o direito à indenização resultante é suficiente para transferir de volta o valor que porventura tenha migrado sem causa do patrimônio do lesado para o patrimônio do responsabilizado civilmente, não há que se falar em enriquecimento sem causa.

Com efeito, a responsabilidade civil apenas visa a restabelecer a situação patrimonial em que a vítima se encontraria, caso o evento danoso não tivesse se verificado. No entanto, a eliminação do enriquecimento resulta como consequência da obrigação de indenizar o dano, pois, à medida em que o ofensor é compelido a dar à vítima o que tem a menos no seu patrimônio, acaba se despojando do eventual lucro auferido com a interferência no direito alheio $^{108}$.

Assim, para que a subsidiariedade embarace o surgimento da pretensão restitutória, é necessário que os remédios alternativos previstos no ordenamento jurídico sejam concretamente suficientes para instrumentalizar a restituição do indevidamente auferido.

Caso exista um remédio jurídico apto, em abstrato, a sanar o enriquecimento, mas que não se revista de efetividade na situação concreta devido à ausência de algum elemento do seu suporte fático, a aplicação do direito restitutório não será afastada pela regra da subsidiariedade. Por exemplo, o fato de que o incremento patrimonial gerado pela intervenção ilícita poderia, em tese, ser revertido pela responsabilidade civil, não pode

\footnotetext{
${ }^{107}$ MICHELON Jr., 2007, p. 264.

${ }^{108}$ PEREIRA COELHO, 1999, pp. 21-22.
} 
constituir óbice à pretensão restitutória, caso o titular do direito não sofra qualquer dano, frustrando a possibilidade de pleitear indenização em juízo.

Entretanto, se o remédio alternativo se tornar ineficaz em decorrência de um impedimento de direito, então a subsidiariedade afastará a aplicação da cláusula geral que veda o enriquecimento sem causa. Com efeito, o enriquecimento sem causa não pode ser utilizado como sucedâneo de outros direitos na hipótese de estes estarem encobertos pela prescrição, ou de terem sido erradicados pela usucapião, ou pela decadência do direito de anulação ou resolução.

Em certas hipóteses, portanto, o ordenamento jurídico tolerará o enriquecimento sem causa, optando por não autorizar a sua reversão, seja para estabelecer uma sanção à inércia do empobrecido, ou alternativamente, devido à necessidade de tutelar a boa-fé e estimular a observância de determinadas regras de conduta ${ }^{109}$.

CLÁUdio MiCHELON JR. relata que os óbices jurídicos que limitam ou eliminam o recurso aos remédios alternativos são fruto de uma ponderação do legislador entre o princípio da conservação estática dos patrimônios, que fundamenta o enriquecimento sem causa, e outros princípios diretivos do sistema:

Prazos prescricionais (seja sobre prescrição extintiva, seja sobre prescrição aquisitiva) ou regras sobre a caducidade (culposa ou não) de direitos podem ser fundadas em vários princípios justificadores diferentes. Assim, regras que estabelecem prazos de prescrição extintiva respondem, entre outras, às necessidades de certeza e segurança do direito. A regra que estabelece a perda de um direito de anulação nos casos em que o devedor pratica atos incompatíveis com a intenção de anular o negócio é fundada no imperativo da boa-fé objetiva, que manda preservar as relações de lealdade e confiança no tráfico de bens jurídicos. Outros exemplos poderiam ser trazidos à colação, mas desde já é possível constatar que muitas dessas regras limitativas (ou erradicadoras) de remédios alternativos para proceder à restituição do enriquecimento sem causa são resultantes da

\footnotetext{
109 "Por último, sucede ainda, embora a título excepcional, que à lei não repugna criar ou manter em certos casos, no todo ou em parte, situações de enriquecimento à custa de outrem, umas vezes como sanção contra a conduta do lesado, outras como meio de tutela da boa-fé ou da certeza do direito, outras como processo de estimular a observância de determinadas regras de conduta.". ANTUNES VARELA, 1991, p. 488-489.
} 
incidência de outros princípios fundantes do direito privado, como o princípio da boa-fé.

Esses princípios funcionariam como princípios limitadores do princípio do enriquecimento sem causa, que, como já foi ressaltado, é o princípio da conservação estática dos patrimônios. As regras que excluem a efetividade dos remédios alternativos não seriam, portanto, meros caprichos do legislador, mas resultariam de outros princípios fundantes do direito privado ${ }^{110}$.

Com efeito, o enriquecimento sem causa é um instituto de grande amplitude, que se espraia por todo o ordenamento em hipóteses típicas, como o pagamento indevido (CC, arts. 876 a 883), o regime dos frutos e das benfeitorias (CC, art. 1219 e ss.), a gestão de negócios (CC, art. 861 e ss.), a avulsão (CC, art. 1251), a especificação (CC, art. 1271), a confusão, comissão e adjunção (CC, arts. 1.272 a 1.274$)^{111}$.

Assim é que, sempre que a lei se refira aos efeitos econômicos de certa deslocação patrimonial, regulando-os por meio de uma obrigação imposta ao beneficiário com conteúdo diferente do da obrigação fundada no enriquecimento sem causa, é necessário proceder à análise da ratio legis, para que se possa verificar se as normas tomadas em consideração esgotam toda a regulamentação jurídica da situação de fato. Se a resposta for positiva, tais normas afastarão o recurso ao enriquecimento sem causa, por força do art. 886 do Código Civil ${ }^{112}$.

Se a resposta for negativa, é porque "as normas concorrentes não esgotam o sentido normativo da situação de fato, estas não afastarão o recurso complementar ao enriquecimento sem causa. Foi assim que vimos suceder com o concurso entre a responsabilidade civil e enriquecimento sem causa." $"$.

\footnotetext{
${ }^{110}$ MICHELON Jr., 2007, p. 29.

${ }^{111}$ LINS, Thiago. O Lucro da Intervenção e o Direito à Imagem. Rio de Janeiro: Lumen Juris, 2016. p. 80 .

${ }^{112}$ GUEDES, 2011, p. 225.

${ }^{113}$ LEITE DE CAMPOS, Diogo José Paredes. Enriquecimento sem causa: responsabilidade civil e nulidade. In: RT 560, São Paulo: Ed. RT, p. 264, jun./1982.
} 
No âmbito da violação do direito de propriedade, por exemplo, não há norma específica que promova a exclusão do benefício econômico ilegitimamente obtido do patrimônio do agente, razão pela qual o instituto da vedação ao enriquecimento sem causa poderá ser chamado a atuar para retirar do patrimônio do interventor o lucro obtido a partir da intervenção injustificada em direitos ou bens alheios ${ }^{114}$.

De acordo com MARCELO TRINDADE a finalidade da subsidiariedade é de impedir a utilização da actio in rem verso como mecanismo para burlar regras específicas, previstas em outros dispositivos do Código Civil ou da legislação extravagante, que limitam, afastam, ou instituem requisitos específicos para a restituição, em homenagem a outros interesses priorizados pelo legislador ${ }^{115}$ :

(...) com a regra da subsidiariedade visa-se à preservação da disciplina específica de um grande número de situações para as quais a lei adotará soluções múltiplas, estabelecendo requisitos para o cabimento da ação, exceções a seu cabimento ou limitações quantitativas da restituição, com isto impedindo ou limitando a reversão do enriquecimento.

Alerta, ainda, que as disciplinas específicas de cada situação tornarse-iam "letra morta se fosse admitida a utilização da actio in rem verso nas hipóteses em que incidissem tais requisitos, exceções e limitações, impedindo ou restringindo a reversão do enriquecimento".

Destarte, a subsidiariedade refere-se à aplicação do princípio geral da vedação ao enriquecimento sem causa frente a hipóteses regulamentadas de forma específica pelo legislador ${ }^{116}$. Assim, não poderia um possuidor pretender o ressarcimento de benfeitorias voluptuárias alegando a vedação geral ao enriquecimento sem causa, já que sua aplicação é subsidiária às

\footnotetext{
114 TERRA; GUEDES, 2015, p. 13.

115 TRINDADE, Marcelo. Enriquecimento sem causa e repetição de indébito: observações à luz do Código Civil de 2002. Revista Trimestral de Direito Civil, v. 5, nº 18, p. 235-261, abr./jun. 2004. 116 VARELA, João de Matos Antunes. Direito das obrigações. Rio de Janeiro. Forense, 1977. p. 2002.
} 
regras específicas que regulam a indenização de benfeitorias conforme o animus do possuidor (arts. 1.219 e $1.220, \mathrm{CC})^{117}$.

De acordo com PIETRO SIRENA ${ }^{118}$, em comentário ao art. 2.042 do Código italiano (que serviu de inspiração para o art. 886 do Código brasileiro), a razão subjacente ao dispositivo não é o antigo medo de que o enriquecimento sem causa se torne um instrumento subversivo do direito positivo, mas sim a necessidade de evitar, nas situações em que o suporte fático do art. 884 incidisse concorrentemente ao suporte fático de outra fonte obrigacional (notadamente da responsabilidade civil), que o ofendido/empobrecido pudesse exercer ambas as ações.

Sendo essa a interpretação teleológica do art. 886, do Código Civil, a cumulação entre a pretensão de restituição do enriquecimento sem causa e a pretensão de indenização por responsabilidade civil é possível contanto que não tenham o mesmo objeto, isso é, que o enriquecimento a ser restituído já não estivesse totalmente abarcado pelo dano a ser indenizado.

Em todo o caso, nas hipóteses de enriquecimento por intervenção, em que os lucros obtidos pelo interventor são superiores aos danos causados, a responsabilidade civil não poderá ser considerada um "outro meio" capaz de obstar o exercício da ação de enriquecimento sem causa. Afinal, por intermédio da ação de responsabilidade civil, o titular do direito apenas conseguirá obter a compensação pelos danos sofridos, mas esta jamais poderá, isoladamente, operar a integralidade da restituição que seria devida em função do instituto do enriquecimento sem causa ${ }^{119}$, permitindo, consequentemente, que o interventor mantenha consigo parte do proveito auferido.

\footnotetext{
${ }^{117}$ KONDER, 2017, p. 240.

118 SIRENA, Pietro. Note Critiche sulla sussidiarietà dell'azione generale di arrichimento senza causa. Rivista Trimestrale di Diritto e Procedura Civile, ano XLII, n. 2, p. 249-290, p. 116. mar./abr. 1997.

${ }^{119}$ SAVI, 2012, p. 119.
} 
Dessa forma, o requisito da subsidiariedade precisa ser relativizado, a fim de que a verificação da remoção parcial do enriquecimento pela ação indenizatória não impeça que o saldo do lucro obtido através da ingerência antijurídica de bens alheios seja expurgado do patrimônio do enriquecido, por meio da actio in rem verso. Essa é a opinião de CARLOS NELSON Konder, Diogo LeITE DE CAMPOS e ClÁUdio MiChELON:

Assim até o ponto em que a vítima tem meios para se ressarcir do dano, presentes os pressupostos da responsabilidade civil, não se aplica o enriquecimento sem causa, mas a partir do ponto em que o lucro obtido extravasa o dano, ou que falta algum outro requisito para a demanda indenizatória, não haveria obstáculo à aplicação do enriquecimento sem causa ${ }^{120}$.

O enriquecimento que a instituição da responsabilidade civil não tiver deslocado será transferido através de normas do enriquecimento sem causa. Hipótese em que terá havido uma simples consunção imputa de normas.

Nesses termos, o enriquecimento do lesante será suprimido através de dois institutos. Primeiro, imediatamente, através das normas de responsabilidade civil.

Depois, se subsistir uma parcela de enriquecimento, esta será removida diretamente por meio do instituto do enriquecimento sem causa. Em conclusão: o montante da obrigação de indenizar ou de restituir a que estará adstrito o que interveio nos bens alheios poderá ultrapassar a medida do seu enriquecimento - tudo dependerá do montante do dano a reparar. Mas nunca será inferior ao montante do enriqueciment ${ }^{121}$.

Nesses casos, nada obsta que surja um direito de restituição do valor equivalente à diferença entre a indenização e o valor que seria devido em função da ocorrência de enriquecimento sem causa (essa a opinião da maior parte da doutrina lusobrasileira). Na verdade, em caso de necessidade de ação judicial, seria possível, no mais das vezes, cumular os pedidos ${ }^{122}$.

\footnotetext{
${ }^{120}$ KONDER; SAAR, 2017, p. 155.

${ }^{121}$ CAMPOS, Diogo Leite de. Enriquecimento sem causa, responsabilidade civil e nulidade. Revista dos Tribunais, v. 560, p. 264-266, jun. 1982.

${ }^{122}$ MICHELON Jr., 2007, p. 264.
} 
Conclui-se, portanto, que é lícita e juridicamente possível a cumulação das pretensões indenizatória e restitutória pelo titular do direito usurpado sem autorização. Afinal, o caráter residual da actio in rem verso visa a impedir que o lesado-empobrecido pleiteie duas vezes a mesma quantia, uma vez a título de dano sofrido e outra de enriquecimento obtido pelo interventor, em flagrante bis in idem.

Por conseguinte, nas situações em que o direito à indenização abarca apenas uma porcentagem do enriquecimento, é somente sobre esta parte que haveria perigo de duplicação de créditos. Dessa forma, quanto ao restante do valor do enriquecimento, subsiste o direito de crédito do empobrecido à pretensão restitutória. 


\section{CONCLUSÃO}

No cenário atual, a interferência desautorizada em situações jurídicas subjetivas alheias, de que resulta um lucro para o ofensor, tem dado azo à proliferação de indenizações com viés punitivo, cominadas com o propósito de evitar que o interventor obtenha vantagem pecuniária por meio da sua atuação substancialmente antijurídica.

Referida solução foi fruto de uma construção jurisprudencial difusa que, conquanto imbuída das melhores intenções, não possui previsão legal expressa, ferindo, por conseguinte, princípios de magnitude constitucional como a tipicidade e a legalidade (art. $5^{\circ}$, XXXIX, CRFB/88), além de se mostrar incompatível com a estrutura e a função contemporâneas da responsabilidade civil no direito brasileiro.

Nesse diapasão, o instituto do enriquecimento sem causa afigura-se vocacionado, do ponto de vista estrutural e funcional, a expurgar do patrimônio do interventor os benefícios financeiros granjeados através da exploração de uma utilidade econômica, cuja ordenação substancial de bens aprovada pelo Direito, reservava a outrem.

A doutrina clássica, contudo, induzida a erro pela Teoria Unitária do Deslocamento Patrimonial, arrola o empobrecimento do titular do direito usarpado como requisito para a configuração do locupletamento indevido e limite à obrigação de restituir, apesar dessa concepção não possuir respaldo no art. 884 do Código Civil, culminando por restringir o âmbito de incidência do instituto.

Essa linha de entendimento acabaria por frustrar a restituição do lucro auferido mediante enriquecimento por intervenção, cuja mensuração se obtém a partir da variação patrimonial verificada na esfera jurídica do interventor, e não do eventual desfalque produzido no patrimônio do titular do direito. 
Este trabalho buscou evidenciar a necessidade de se superar as teorias do duplo limite e do deslocamento patrimonial, mostrando que essa corrente doutrinária não possui supedâneo na legislação pátria.

Por fim, enfrentou-se o requisito da subsidiariedade, estabelecido no art. 886 do Código Civil, concluindo-se pela viabilidade de as pretensões restitutória e indenizatória serem veiculadas em uma mesma demanda judicial, uma vez que remetem a institutos funcionalmente distintos e não excludentes.

Contudo, para que o instituto adquira relevo pragmático é necessário que os Tribunais assimilem a ampla gama de aplicação da teoria do lucro da intervenção, que desponta como proposição funcionalmente equivalente ao arbitramento de indenizações punitivas, e que melhor se afeiçoa à configuração atual do Direito Civil brasileiro. 


\section{REFERÊNCIAS BIBLIOGRÁFICAS}

ALMEIDA COSTA, Mário Júlio. Direito das obrigações. $7^{\mathrm{a}}$ ed. Coimbra: Almedina, 1998.

ALVIM, Agostinho. Da inexecução das obrigações e suas consequências. $3^{\mathrm{a}}$ ed. atual. Rio de Janeiro; São Paulo: Editora Jurídica e Universitária, 1965.

. Do enriquecimento sem causa, Revista Forense, v. 173, fasc 651652, set.-out. 1957.

ANTUNES VARELA, João de Matos. Das Obrigações em geral. v. 1. $7^{\mathrm{a}}$ ed. Coimbra: Almedina, 1991.

. Das Obrigações em Geral. v. I, 10ª ed., Coimbra: Almedina, 2005.

ARAÚJO, Fernando. Teoria econômica do contrato. Coimbra: Almedina, 2007. p.

ARRUE, Xabier Basozabal. Enriquecimento injustificado por intromision em derecho ajeno. Madrid: Editorial Civitas, 1998.

ASTONE, Francesco. L'arrichimento senza causa. Milano: Giuffrè, 1999.

BOBBIO, Norberto. Contributi ad um dizionario giuridico. Torino: G. Giappichelli, 1994.

. Teoria do ordenamento jurídico. $10^{\mathrm{a}}$ ed. Trad. Maria Celeste C. J.

Santos. Brasília: Universidade de Brasília, 1997.

BODIN DE MORAES, Maria Celina. A constitucionalização do direito civil e seus efeitos sobre a responsabilidade civil. In: SOUZA NETO, Cláudio Pereira; SARMENTO, Daniel (Coord.). A constitucionalização do direito: fundamentos teóricos e aplicações específicas. Rio de Janeiro: Lumen Juris, 2007.

BRASIL. STJ. 2a Seção, REsp 1.439.163/SP, rel. Min. Ricardo Villas Bôas Cueva, rel. p/ acórdão Min. Marco Buzzi, j. 11.03.2015, DJe 22.05.2015.

BRASIL. STJ. $3^{\mathrm{a}}$ T., Rel Min. Castro Filho, Resp 445858/SP, j. 29.11.2005. 
BRASIL. STJ. Terceira Turma, REsp $n^{\circ}$ 1.335.624/RJ, Min. Rel. Ricardo Villas Bôas Cueva, j. 05.12.2013.

BRASIL. TJ-RJ 79. Referência: Uniformização de Jurisprudência $n$. 2004.018.00012 na Apelação Cível no 2004.001.13327, rel. des. Sergio Cavalieri Filho, j. 04.04.2005, votação por maioria, registro de acórdão em 15.07.2005.

BRASIL. TJ-RJ. $9^{\text {a }}$ CC, Rel. Des. Marcus Tullus Alves, $A C$ 20.737/00, j. 13.3.2001.

CAMPOS, Diogo Leite de. A subsidiariedade da obrigação de restituir o enriquecimento (1974). Coimbra: Almedina, 2003.

. Enriquecimento sem causa, responsabilidade civil e nulidade. Revista dos Tribunais, v. 560, jun. 1982.

CAMPOS, Diogo Leite de. Enriquecimento sem causa, responsabilidade civil e nulidade. Revista dos Tribunais, v. 560, jun. 1982.

CASTRO NEVES, José Roberto de. O enriquecimento sem causa: dimensão atual do princípio do direito civil. In: BODIN DE MORAES, Maria Celina (Coord.). Princípios de direito civil contemporâneo. Rio de Janeiro: Renovar, 2006.

FACCHINI NETO, Eugênio. Da responsabilidade civil no novo Código. In. SARLET, Ingo Wolfgang (Org.). O novo Código Civil e a Constituição. Porto Alegre: Livraria do Advogado, 2006.

GALLO, Paollo. Pene private e responsabilità civile. Milano: Giuffrè, 1996. Punitive damages in Italy?. Disponível em:

$<$ http://www.jus.unitn.it/cardozo/review/TOrts/Gallo-1997/gallo.htm>. Acesso em: 17 nov. 2018.

. Il Codice Civile: comentário - arrichimento senza causa, Art. 20412042, Milano: Giuffre, 2003.

GOMES, Júlio Manuel Vieira. $O$ conceito de enriquecimento, $o$ enriquecimento forçado e os vários paradigmas do enriquecimento sem causa. Porto: Universidade Católica Portuguesa, 1998. 
GOMES, Orlando. Tendências modernas na teoria da responsabilidade civil. In: DI FRANCESCO, J. R. P. (Org.). Estudos em Homenagem ao Professor Sílvio Rodrigues. São Paulo: Saraiva, 1980.

GUEDES, Gisela Sampaio da Cruz. Lucros Cessantes: do bom-senso ao postulado normativo da razoabilidade. São Paulo: Editora Revista dos Tribunais, 2011.

KONDER, Carlos Nelson. Dificuldades de uma Abordagem Unitária do Lucro da Intervenção. In: Revista de Direito Civil Contemporâneo. $\mathrm{n}^{\mathrm{o}} 4$, v. 13, out.-dez./2017.

Enriquecimento sem causa e pagamento indevido. In: TEPEDINO, Gustavo (Coord.) Obrigações. Estudos na perspectiva civil-constitucional. Rio de Janeiro: Renovar, 2005.

; SAAR, Patrick. A relativização do Duplo Limite e da Subsidiariedade nas Ações por Enriquecimento sem Causa. In: TEPEDIO, Gustavo et al. (Coord.). Da dogmática à efetividade do Direito Civil: Anais do Congresso Internacional de Direito Civil Constitucional - IV Congresso do IBDCIVIL. Belo Horizonte: Fórum, 2017.

LARENZ, Karl. Derecho de obligaciones. t. I. Jaime Santos Briz (Trad.)., Madrid: Editorial Revista de Derecho Privado, 1958.

LEITÃO, Luís Manuel Teles de Menezes. O enriquecimento sem causa no direito civil: estudo dogmático sobre a viabilidade da configuração unitária do instituto, face à contraposição entre as diferentes categorias de enriquecimento sem causa. Lisboa: Centro de Estudos Fiscais, 1996.

. O enriquecimento sem causa no direito civil: estudo dogmático da configuração unitária do instituto, face à contraposição entre as diferentes categorias do enriquecimento sem causa. Coimbra: Almedina, 2005.

LEITE DE CAMPOS, Diogo José Paredes. Enriquecimento sem causa: responsabilidade civil e nulidade. In: RT 560, São Paulo: Ed. RT, jun./1982.

LEVY, Daniel de Andrade. Responsabilidade civil: de um direito dos danos a um direito das condutas lesivas. São Paulo: Atlas, 2012.

LINS, Thiago. O Lucro da Intervenção e o Direito à Imagem. Rio de Janeiro: Lumen Juris, 2016. 
LOPES, Miguel Maria de Serpa. Curso de Direito Civil.v. 5. Rio de Janeiro: Freitas Basto, 1961.

MENEZES LEITÃO, Luís Manuel Teles de. Direito das Obrigações: introdução, da constituição das obrigações. v. I. 8. ed. Coimbra: Almedina, 2009.

. O enriquecimento sem causa no novo Código Civil brasileiro. $\overline{\text { Revista }}$ CEJ, Brasília, v. 8, n. 25, p. 27, abr./jun. 2004.

O enriquecimento sem causa no direito civil, Coimbra: Almedina, 2005 .

MICHELON Jr., Cláudio. Direito Restitutório: enriquecimento sem causa, pagamento indevido, gestão de negócios. São Paulo: Editora Revista dos Tribunais, 2007.

MORAES, Maria Celina Bodin de. Danos à pessoa humana: uma leitura civil-constitucional dos danos morais. Rio de Janeiro: Renovar, 2003.

MOREIRA, José Carlos Barbosa. O processo penal norte-americano e sua influência. Revista de Direito Renovar. v. 18, p. 54. set./dez. 2000.

MOSCATI, Enrico. Pena privata e autonomia privata. In: VV.AA. Le pene private. Milano: Giuffrè, 1985.

NANNI, Giovanni Ettore. Enriquecimento sem causa: de acordo com o novo Código Civil. São Paulo: Saraiva, 2004.

NEGREIROS, Teresa. Enriquecimento sem causa: aspectos de sua aplicação no Brasil como um princípio geral de direito In: Revista da Ordem dos Advogados. v. 55, n. 3/757-845, Lisboa: dez./1995.

NORONHA, Fernando. Direito das Obrigações: fundamentos do direito das obrigações: introdução à responsabilidade civil. v. 1. $2^{\mathrm{a}}$ ed. São Paulo: Saraiva, 2007.

OSTENDORF, Heribert. Der Vermogensbegriff im Bereicherunsgrund Schadensrecht. BB, 1973. e segs apud GOMES, Júlio Manuel Vieira. In: $O$ conceito de enriquecimento, o enriquecimento forçado e os vários paradigmas do enriquecimento sem causa. Porto: Universidade Católica Portuguesa, 1998. 
PEREIRA COELHO, Francisco Manuel. O enriquecimento e o dano [1970]. Coimbra: Almedina, 1999.

PERLINGIERI, Pietro. O Direito Civil na Legalidade Constitucional. Rio de Janeiro: Renovar, 2008.

SAVI, Sérgio. Responsabilidade civil e enriquecimento sem causa: o lucro da intervenção. São Paulo: Atlas, 2012.

SAVIGNY. System des heutigen romischen Rechts. Berlin: Veit; Scientia Verlag Aalen, 1849, 1981. p. 526-527 apud MENEZES LEITÃO, Luíz Manuel Teles de. O enriquecimento sem causa no novo Código Civil brasileiro: estudo dogmático da configuração unitária do instituto, face à contraposição entre as diferentes categorias do enriquecimento sem causa. Coimbra: Almedina, 2005.

SCHLESINGER, Piero. Arrichimento (azione di), Novissimo digesto italiano. Torino: Utet, v. 1, 1958.

SCHREIBER, Anderson. Arbitramento do dano moral no novo Código Civil. In: Revista Trimestral de Direito Civil. v. 10, Rio de Janeiro: Padma, 2002.

. Direito Civil e Constituição. São Paulo: Atlas, 2013.

. Novos Paradigmas da Responsabilidade Civil: da erosão dos filtros da responsabilidade civil à diluição dos danos. São Paulo: Atlas, 2007.

; SILVA, Rodrigo da Guia. Lucro da Intervenção: Perspectivas de Qualificação e Quantificação In: Direito Civil: Estudos - Coletânea do XV Encontro dos Grupos de Pesquisa - IBDCIVIL. São Paulo: Blucher, 2018.

SCHULZ, Fritz. System der Rechte auf den Eingriffserwerb. Archiv für die civilistische Praxis, 105. Bd., H. 1, 1909.

SILVA, Rodrigo da Guia. Contornos do enriquecimento sem causa e da responsabilidade civil, estudo a partir da diferença entre lucro da intervenção e lucros cessantes. Civilistica.com, a. 5, n. 2, p. 17, 2016.

SIRENA, Pietro. Note Critiche sulla sussidiarietà dell'azione generale di arrichimento senza causa. Rivista Trimestrale di Diritto e Procedura Civile, ano XLII, n. 2, p. 249-290, mar./abr. 1997.

TEPEDINO, Gustavo; SCHREIBER, Anderson. As penas privadas no direito brasileiro. In. GALDINO, Flávio; SARMENTO, Daniel (Org.). Direitos 
Fundamentais: estudos em homenagem ao Professor Ricardo Lobo Torres. Rio de Janeiro: Renovar, 2006.

TERRA, Aline de Miranda Valverde. Função Punitiva do Dano Moral: Análise Crítica e Proposições Funcionalmente Equivalentes. In: Direito civil contemporâneo. Organização CONPEDI/UFS; REZENDE, Elcio Nacur et al. (Coords.). Florianópolis: CONPEDI, 2015a.

. Privação do uso: dano ou enriquecimento por intervenção. Revista Eletrônica Direito e Política, Programa de Pós-Graduação Stricto Sensu em Ciência Jurídica da UNIVALI, Itajaí, v. 9, n. 3, 3º quadrimestre de 2014. Disponível em: $<$ http://www.univali.br/direitoepolitica $>$. Acesso em: 18 nov. 2018.

; GUEDES, Gisela Sampaio da Cruz. Considerações acerca da exclusão do lucro ilícito do patrimônio do agente ofensor. Revista da Faculdade de Direito - RFD-UERJ. Rio de Janeiro, n. 28, p. 19, dez. 2015 b.

THOMPSON FLORES LENZ, Carlos Eduardo. Considerações sobre a indenização por lucros cessantes. Revista do Ministério Público. n ${ }^{\circ} 34 / 90-93$, Porto Alegre: Nova Fase, 1995.

TRABUCCHI, Alberto. Arrichimento (azione di). Enciclopedia del diritto. Milano: Giuffrè, v. 3, 1957.

TRINDADE, Marcelo. Enriquecimento sem causa e repetição de indébito: observações à luz do Código Civil de 2002. Revista Trimestral de Direito Civil, v. 5, no 18, abr./jun. 2004.

VALLE FERREIRA, José G. do. Enriquecimento sem causa, 3. ed. Belo Horizonte: Livraria Oscar Nicolau, s/d.

VARELA, João de Matos Antunes. Das obrigações em geral. v. 1. $9^{\mathrm{a}}$ ed. Coimbra: Livraria Almedina, 1996.

. Direito das obrigações. Rio de Janeiro. Forense, 1977.

. Direito das obrigações. Rio de Janeiro. Forense, 1977.

VON CAENNERER, Ernst. Bereicherung and unerlaubte Handlung em HANS DÖLLE, Max Rheinstein; ZWEIGERT, Jobrad (Org.). Fetschrift für Ernst Rabekm I - Rechtsvergleichung und internattionales Privatrecht, Tübingen, Mohr, 1954. p. 333-401 apud LEITÃO, Luís Manuel Teles de Menezes. O enriquecimento sem causa no direito civil: estudo dogmático da 
configuração unitária do instituto, face à contraposição entre as diferentes categorias do enriquecimento sem causa. Coimbra: Almedina, 2005.

WILBURG, Walter. Die Lehre von der ungerechtfertigten Bereicherung nach österreuchischem und deutschem Recht. Kritik und Aufbau, Graz, Leuschner \& Lubensky, 1934 apud LEITÃO, Luís Manuel Teles de Menezes. O enriquecimento sem causa no direito civil: estudo dogmático da configuração unitária do instituto, face à contraposição entre as diferentes categorias do enriquecimento sem causa. Coimbra: Almedina, 2005.

ZIFF, Bruce. The great onyx cave cases - a micro-history. Northern Kentucky Law Review. Highland Heights, v. 40, n.1, p. 1-48, 2013. 